Prepared in cooperation with the City of Colorado Springs, Water Resources Engineering Division, Public Works Department and Colorado Springs Utilities

\title{
Changes in Biological Communities of the Fountain Creek Basin, Colorado, 2003-2016, in Relation to Antecedent Streamflow, Water Quality, and Habitat
}

Scientific Investigations Report 2017-5162

U.S. Department of the Interior

U.S. Geological Survey

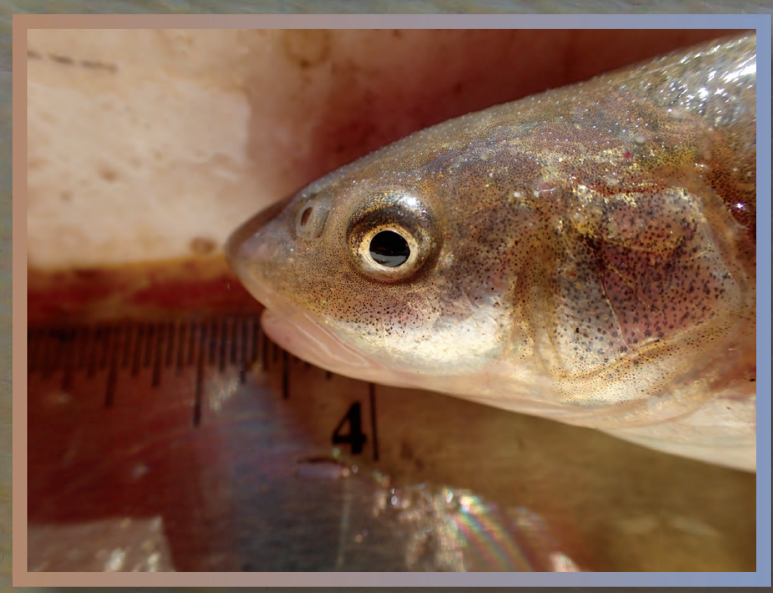


Cover. Fish photo: Flathead chub (Platygobio gracilis) from Fountain Creek, Colorado. (Photo by James Roberts, U.S. Geological Survey) Mayfly photo: Mayfly (Ephemeroptera) adult from Fountain Creek, Colorado. (Photo by Erin J.P. Jeffery, U.S. Geological Survey) River photo: Fountain Creek at Pinion, Colorado. (Photo by James Roberts, U.S. Geological Survey) 


\section{Changes in Biological Communities of the Fountain Creek Basin, Colorado, 2003-2016, in Relation to Antecedent Streamflow, Water Quality, and Habitat}

By James J. Roberts, James F. Bruce, and Robert E. Zuellig

Prepared in cooperation with the City of Colorado Springs, Water Resources

Engineering Division, Public Works Department and Colorado Springs Utilities

Scientific Investigations Report 2017-5162 


\title{
U.S. Department of the Interior \\ RYAN K. ZINKE, Secretary
}

\section{U.S. Geological Survey \\ William H. Werkheiser, Deputy Director exercising the authority of the Director}

\author{
U.S. Geological Survey, Reston, Virginia: 2018
}

For more information on the USGS - the Federal source for science about the Earth, its natural and living resources, natural hazards, and the environment-visit https://www.usgs.gov or call 1-888-ASK-USGS.

For an overview of USGS information products, including maps, imagery, and publications, visit https://store.usgs.gov.

Any use of trade, firm, or product names is for descriptive purposes only and does not imply endorsement by the U.S. Government.

Although this information product, for the most part, is in the public domain, it also may contain copyrighted materials as noted in the text. Permission to reproduce copyrighted items must be secured from the copyright owner.

Suggested citation:

Roberts, J.J., Bruce, J.F., and Zuellig, R.E., 2018, Changes in biological communities of the Fountain Creek Basin, Colorado, 2003-2016, in relation to antecedent streamflow, water quality, and habitat: U.S. Geological Survey Scientific Investigations Report 2017-5162, 20 p., https://doi.org/10.3133/sir20175162.

ISSN 2328-0328 (online) 


\section{Acknowledgments}

The authors thank the City of Colorado Springs, Water Resources Engineering Division, Public Works Department and Colorado Springs Utilities for their support. Gary Dowler, Paul Foutz, and numerous technicians of the Colorado Division of Wildlife (now Colorado Parks and Wildlife) contributed greatly to the fish-sampling efforts. David Walters (U.S. Geological Survey), Matt Haworth (Colorado State University), and William Battaglin (U.S. Geological Survey) provided thoughtful reviews and comments that improved earlier versions of this manuscript. The authors also thank the U.S. Geological Survey hydrographers that collected, compiled, and analyzed streamflow measurement data.

\section{Contents}

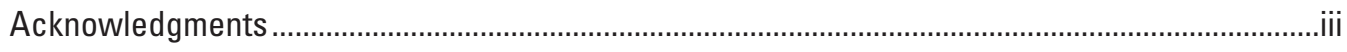

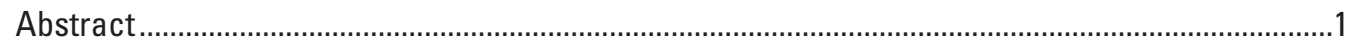

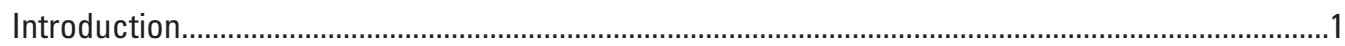

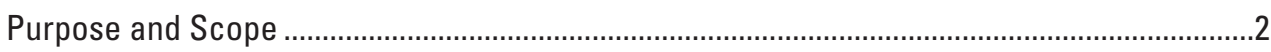

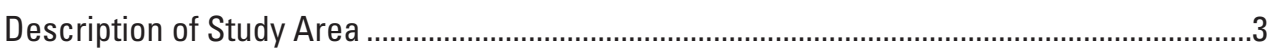

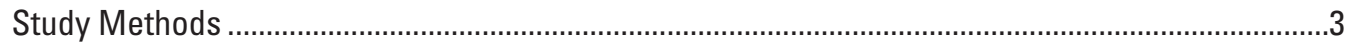

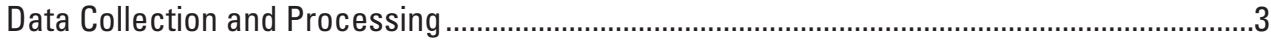

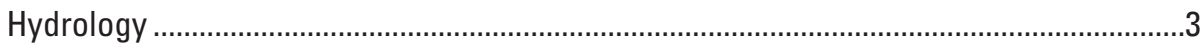

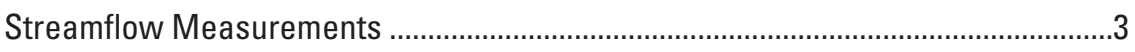

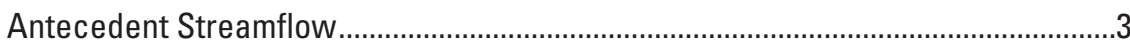

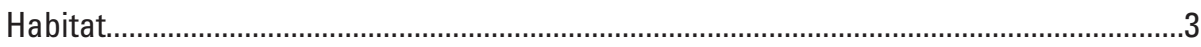

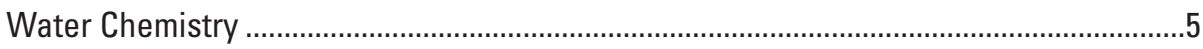

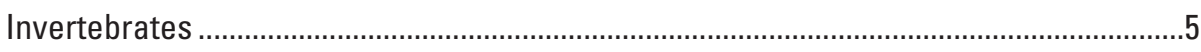

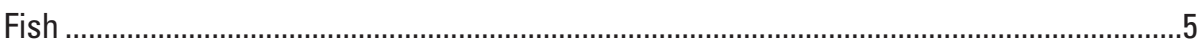

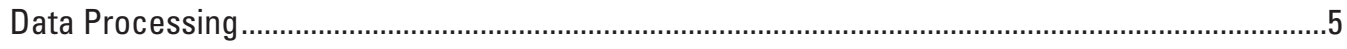

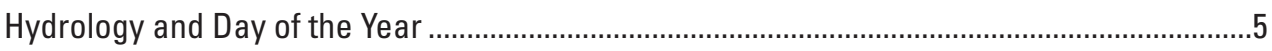

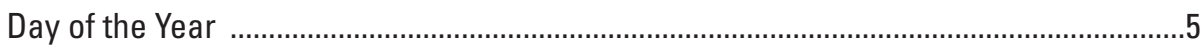

Antecedent Streamflow...........................................................................................

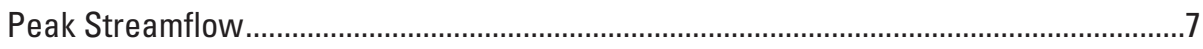

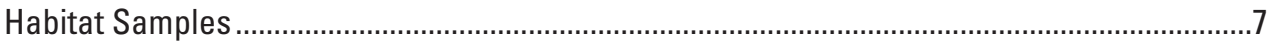

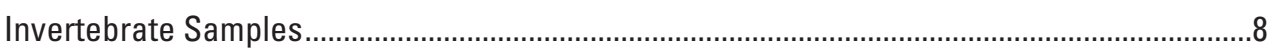

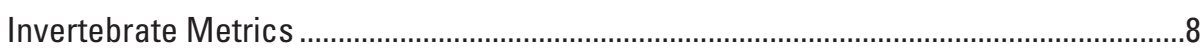

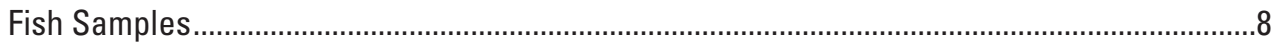

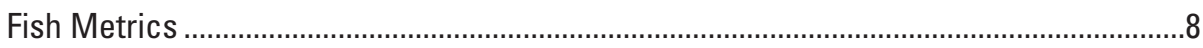

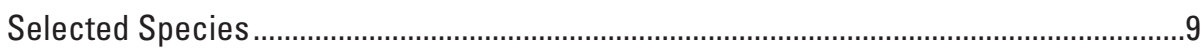

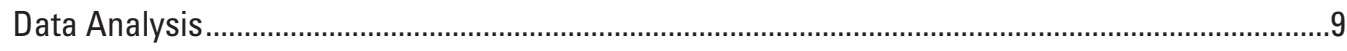

Changes in Biological Communities of Fountain Creek Basin .......................................................10

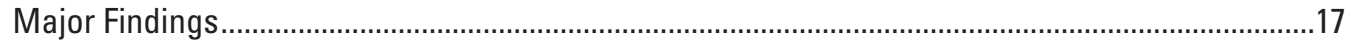

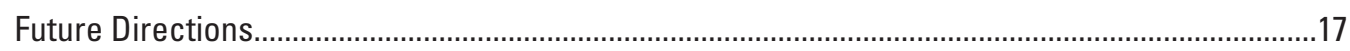

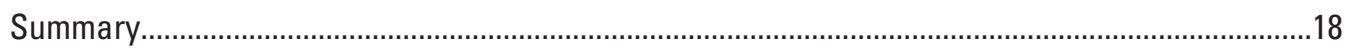

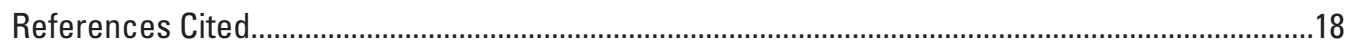




\section{Figures}

1. Map showing locations of sampling sites in the Fountain Creek Basin, Colorado, 2003-2016

2. General flow diagram illustrating data analysis steps for detecting and explaining trends in invertebrate and fish communities, Fountain Creek Basin, Colorado, 2003-2016

3. Map showing the spatial distribution of trends in fish and invertebrate metrics in the Fountain Creek Basin, Colorado, 2003-2016.

4. Number of trends for invertebrate and fish metrics explained by streamflow, habitat, or water-quality variables and the number unexplained by the data

5. Number of trends in fish and invertebrate metrics related to streamflow (masked by streamflow, explained by streamflow, or not explained by streamflow), explained by habitat, or explained by water-quality variables and the number unexplained given the data

6. Scatterplot of flathead chub age-0 fish versus the number of peak flow days in a year

\section{Tables}

1. Description of sampling sites in the Fountain Creek Basin, Colorado, 2003-2016 ...........2

2. Fish species collected by the U.S. Geological Survey and Colorado Parks and Wildlife in the Fountain Creek Basin, Colorado, 2003-2016.

3. Environmental variables used to detect monotonic trends in invertebrate and fish biological community structure at selected sites in the Fountain Creek Basin, Colorado, 2003-2016.

4. Metric descriptions for invertebrate and fish communities calculated for monotonic trend assessment in the Fountain Creek Basin, Colorado, 2003-2016............8

5. Monotonic trends in invertebrate and fish metrics explained by antecedent streamflow variables in the Fountain Creek Basin, Colorado, 2003-2016.

6. Streamflow-adjusted significant monotonic trends in invertebrate and fish metrics explained by habitat and water-quality variables in the Fountain Creek Basin, Colorado, 2003-2016

7. Monotonic trends in fish metrics explained by antecedent streamflow variables in the Fountain Creek Basin, Colorado, 2003-2016

8. Monotonic trends in fish metrics explained by habitat and water-quality variables in the Fountain Creek Basin, Colorado, 2003-2016.. 


\section{Conversion Factors}

U.S. customary units to International System of Units

\begin{tabular}{lcl}
\hline & Multiply & \multicolumn{1}{c}{ By obtain } \\
\hline & Length & \\
\hline inch (in.) & 2.54 & centimeter $(\mathrm{cm})$ \\
inch (in.) & 25.4 & millimeter $(\mathrm{mm})$ \\
foot (ft) & 0.3048 & meter $(\mathrm{m})$ \\
\hline & Area & \\
\hline acre & 4,047 & square meter $\left(\mathrm{m}^{2}\right)$ \\
square mile $\left(\mathrm{mi}^{2}\right)$ & 259.0 & hectare $(\mathrm{ha})$ \\
square mile $\left(\mathrm{mi}^{2}\right)$ & 2.590 & square kilometer $\left(\mathrm{km}^{2}\right)$ \\
\hline & Flow rate & \\
\hline cubic foot per second $\left(\mathrm{ft}^{3} / \mathrm{s}\right)$ & 0.02832 & cubic meter per second $\left(\mathrm{m}^{3} / \mathrm{s}\right)$ \\
\hline
\end{tabular}

International System of Units to U.S. customary units

\begin{tabular}{lll}
\hline \multicolumn{1}{c}{ Multiply } & By & \multicolumn{1}{c}{ To obtain } \\
\hline centimeter $(\mathrm{cm})$ & Length & \\
millimeter $(\mathrm{mm})$ & 0.3937 & inch (in.) \\
meter $(\mathrm{m})$ & 0.03937 & inch (in.) \\
& 3.281 & foot $(\mathrm{ft})$ \\
\hline cubic meter per second $\left(\mathrm{m}^{3} / \mathrm{s}\right)$ & Flow rate & \\
\hline
\end{tabular}

Temperature in degrees Celsius $\left({ }^{\circ} \mathrm{C}\right)$ may be converted to degrees Fahrenheit $\left({ }^{\circ} \mathrm{F}\right)$ as follows:

$$
{ }^{\circ} \mathrm{F}=\left(1.8 \times{ }^{\circ} \mathrm{C}\right)+32 .
$$

Temperature in degrees Fahrenheit $\left({ }^{\circ} \mathrm{F}\right)$ may be converted to degrees Celsius $\left({ }^{\circ} \mathrm{C}\right)$ as follows:

$$
{ }^{\circ} \mathrm{C}=\left({ }^{\circ} \mathrm{F}-32\right) / 1.8 .
$$

\section{Datum}

Vertical coordinate information is referenced to the North American Vertical Datum of 1988 (NAVD 88).

Horizontal coordinate information is referenced to the North American Datum of 1983 (NAD 83).

Elevation, as used in this report, refers to distance above the vertical datum. 


\section{Abbreviations}

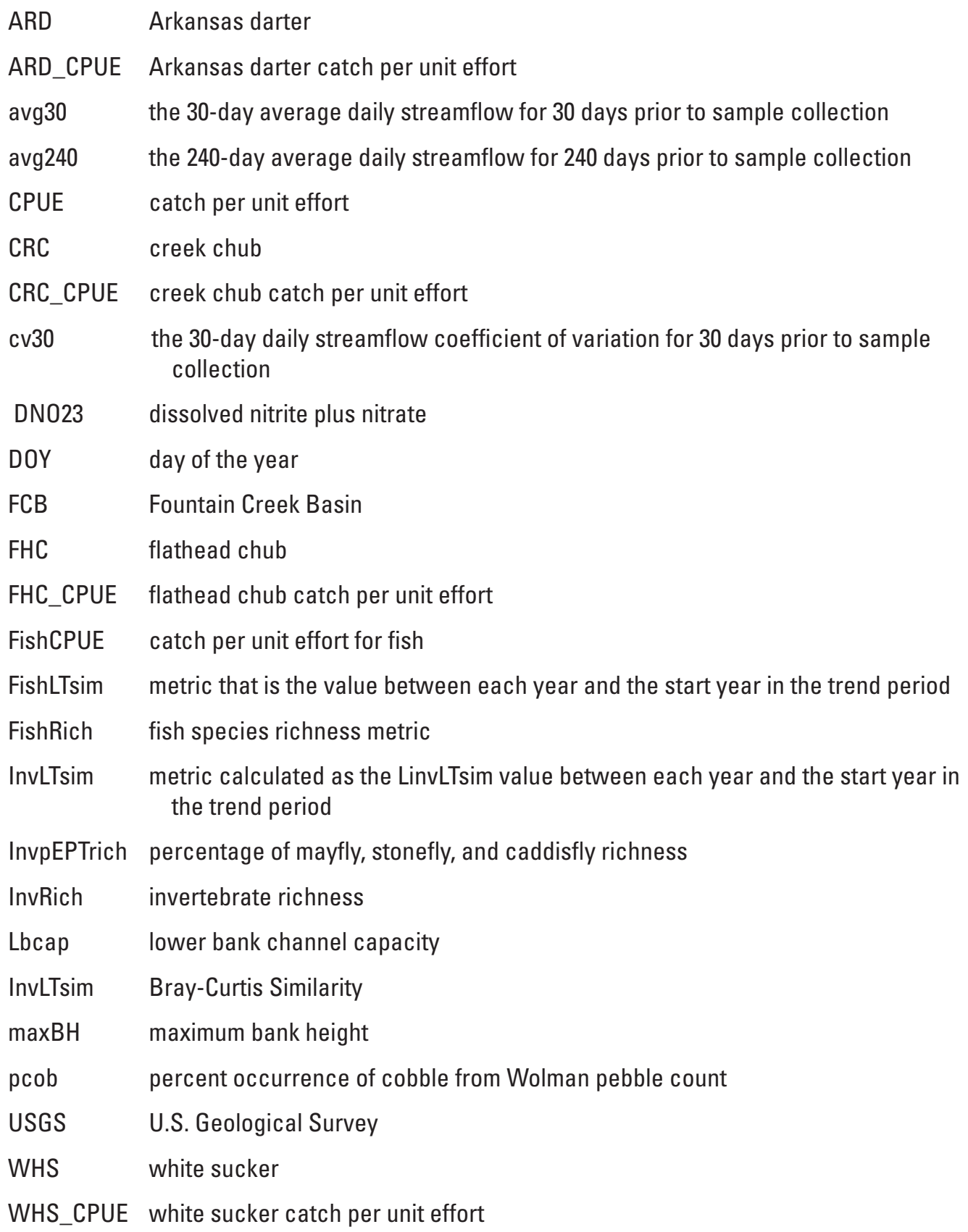




\title{
Changes in Biological Communities of the Fountain Creek Basin, Colorado, 2003-2016, in Relation to Antecedent Streamflow, Water Quality, and Habitat
}

\author{
By James J. Roberts, James F. Bruce, and Robert E. Zuellig
}

\section{Abstract}

The analysis described in this report is part of a longterm project monitoring the biological communities, habitat, and water quality of the Fountain Creek Basin. Biology, habitat, and water-quality data have been collected at 10 sites since 2003. These data include annual samples of aquatic invertebrate communities, fish communities, water quality, and quantitative riverine habitat. This report examines trends in biological communities from 2003 to 2016 and explores relationships between biological communities and abiotic variables (antecedent streamflow, physical habitat, and water quality). Six biological metrics (three invertebrate and three fish) and four individual fish species were used to examine trends in these data and how streamflow, habitat, and (or) water quality may explain these trends. The analysis of 79 trends shows that the majority of significant trends decreased over the trend period. Overall, 19 trends before adjustments for streamflow in the fish (12) and invertebrate (7) metrics were all decreasing except for the metric Invertebrate Species Richness at the most upstream site in Monument Creek. Seven of these trends were explained by streamflow and four trends were revealed that were originally masked by variability in antecedent streamflow. Only two sites (Jimmy Camp Creek at Fountain, CO and Fountain Creek near Pinon, CO) had no trends in the fish or invertebrate metrics. Ten of the streamflow-adjusted trends were explained by habitat, one was explained by water quality, and five were not explained by any of the variables that were tested. Overall, from 2003 to 2016, all the fish metric trends were decreasing with an average decline of 40 percent, and invertebrate metrics decreased on average by 9.5 percent. A potential peak streamflow threshold was identified above which there is severely limited production of age- 0 flathead chub (Platygobio gracilis).

\section{Introduction}

Examining patterns in biological communities through time is a fundamental component of monitoring the health of aquatic systems. However, the direction and magnitude of changes in biological communities should be paired with the biotic and abiotic processes that are influencing or driving these patterns (for example, see Oelsner and others, 2017). As a result of human land use and development, most streams in the western Great Plains and Rocky Mountain transition zone (that is, the area between the two distinctive landforms that make up the western Great Plains and the Rocky Mountains) have highly altered hydrologic regimes, habitat, and water quality (Edelmann and others, 2002; Dodds and others, 2004; Mau and others, 2007). These stressors are driving the widespread declines and extirpations of aquatic biota (Falke and others, 2011; Perkin and others, 2015). Conversely, the small number of streams that still experience a natural flow regime in this region still have largely intact biological communities (Bestgen and others, 2017). Two aspects of streamflow that have been shown to negatively influence the persistence, growth, and population dynamics of stream biota are increased stream intermittency and augmented peak streamflow (both frequency and magnitude) (Durham and Wilde, 2006; Perkin and others, 2015; Haworth and Bestgen, 2017). These results suggest that the persistence of streamflow is a major driver of biological community dynamics in prairie streams of the western Great Plains and in plains streams that transition from the Rocky Mountains.

The importance of maintaining or managing a natural flow regime to protect the structure and function of stream ecosystems has long been recognized (Scholosser, 1985; Poff and Allan, 1995; Poff and others, 1997). More recently, studies have focused on changes in streamflow at the regional scale; these studies suggest that alterations to flow regimes vary regionally along with the responses of the ecology of these systems (Carlisle and others, 2011). Attempts to address the threats from changes in the flow regime have included recommendations from regional management plans (Kiernan and others, 2012) to global reviews and analyses (Poff and Matthews, 2013). One specific streamflow effect is prior 
(antecedent) streamflow, which influences biological communities in two important ways (Rolls and others, 2012). First, patterns in streamflow prior to sampling can influence the capture probability of biota (invertebrates and fish) essential to monitoring biological communities (Biggs and others, 2005). Second, streamflow patterns from the previous season(s) can influence abundance of taxa (Fritz and Dodds, 2005). Therefore, it is important to account for antecedent streamflow when analyzing trends in stream biological assemblages.

Within the Fountain Creek Basin (FCB), the flow regime has been altered from a historical intermittent stream to a perennial flowing, fluvial system (Stogner, 2000; Edelmann and others, 2002). These changes are owing to transmountain water exchange and human land use in the watershed, which have augmented streamflow by means of hydrologic alterations to FCB streams (for example, the addition of irrigation return flows and direct stormwater drainage). Previous analyses have shown that streamflow is an important predictor of both fish and invertebrate community attributes (Zuellig and others, 2008). In addition, water quality and habitat are also drivers of biological communities in the FCB (Zuellig and others, 2008, 2010). However, these previous analyses were performed over short time frames and did not include antecedent streamflow variability coupled with robust trend analyses. To analyze and interpret how the biological communities of the FCB may have changed over the trend period, the U.S. Geological Survey (USGS), in cooperation with the City of Colorado Springs, Water Resources Engineering Division, Public Works Department and Colorado Springs Utilities, performed a robust trend analysis for the period 2003-2016 that included important covariates describing antecedent streamflow conditions, water quality, and habitat.
Few studies have used long-term datasets of streamflow, water quality, and biology to analyze how the biological communities of western Great Plains prairie streams and Rocky Mountain transition-zone streams are changing through time. This lack of studies is likely because high-quality, long-term datasets that link biology, habitat, streamflow, and water quality are extremely rare and difficult to maintain. Since the beginning of the 21 st century, the USGS and its cooperators have created a high-quality dataset that is ideal for trend analysis (Mau and others, 2007; Zuellig and others, 2008, 2010). The consistency and scope of the biological sampling is unique in temporal (annually for 14 years) and spatial (10 sites) coverage; however, there are gaps in some water-quality measurements. The FCB is important habitat for at least four fish species of State and Federal conservation concern (Rahel and Thel, 2004; Colorado Parks and Wildlife, 2017): greenback cutthroat trout (Oncorhynchus clarkii stomias), flathead chub (Platygobio gracilis; FHC), Southern redbelly dace (Chrosomus erythrogaster), and Arkansas darter (Etheostoma cragini; ARD), so results from this analysis are important for management and conservation plans.

\section{Purpose and Scope}

The purpose of this report is to evaluate the influence of antecedent streamflow, habitat, and water quality on the stability of invertebrate and fish communities at 10 sites (table 1) in the FCB from 2003 to 2016 . Each year, fish, invertebrate, and habitat data were collected at each site. A total of 140 qualitative, multihabitat invertebrate samples and 136 fish community samples were collected over the study period. The fish data, as well as the habitat data, can be obtained at https://internal. aquatic.biodata.usgs.gov/login.jsp and found by searching

Table 1. Description of sampling sites in the Fountain Creek Basin, Colorado, 2003-2016.

[ID, identification; USGS, U.S. Geological Survey; NAVD 88, North American Vertical Datum of 1988; ft, foot; mi², square mile; m, meter; abv, above; blw, below]

\begin{tabular}{|c|c|c|c|c|c|}
\hline $\begin{array}{l}\text { Site } \\
\text { ID }^{1}\end{array}$ & $\begin{array}{c}\text { USGS } \\
\text { station } \\
\text { number }^{2}\end{array}$ & $\begin{array}{c}\text { Station } \\
\text { name }^{2}\end{array}$ & $\begin{array}{c}\text { Elevation } \\
\text { NAVD } 88 \\
\text { (ft) }\end{array}$ & $\begin{array}{c}\text { Drainage } \\
\text { area } \\
\left(\mathrm{mi}^{2}\right)\end{array}$ & $\begin{array}{c}\text { Reach } \\
\text { length } \\
\text { (m) }\end{array}$ \\
\hline 1 & 07103700 & Fountain Creek near Colorado Springs, CO & 6,110 & 103 & 150 \\
\hline 2 & 07103970 & Monument Creek abv Woodmen Rd at Colorado Springs, CO & 6,270 & 181 & 150 \\
\hline 3 & 07104905 & Monument Creek at Bijou Street at Colo. Springs, CO & 5,980 & 235 & 250 \\
\hline 4 & 07105500 & Fountain Creek at Colorado Springs, $\mathrm{CO}$ & 5,900 & 392 & 175 \\
\hline 5 & 07105530 & Fountain Creek blw Janitell Road blw Colo. Springs, CO & 5,840 & 413 & 300 \\
\hline 6 & 07105800 & Fountain Creek at Security, $\mathrm{CO}$ & 5,640 & 495 & 300 \\
\hline 7 & 07105900 & Jimmy Camp Creek at Fountain, $\mathrm{CO}^{3}$ & 5,530 & 65.6 & 150 \\
\hline 8 & 07106000 & Fountain Creek near Fountain, $\mathrm{CO}$ & 5,355 & 681 & 300 \\
\hline 9 & 07106300 & Fountain Creek near Pinon, $\mathrm{CO}$ & 4,990 & 849 & 300 \\
\hline 10 & 07106500 & Fountain Creek at Pueblo, $\mathrm{CO}$ & 4,705 & 926 & 300 \\
\hline
\end{tabular}


by USGS station number (see table 1). The invertebrate data, along with the fish and habitat data used in these analyses, are available and archived in the project data release (Roberts and others, 2017). The fish, invertebrate, and habitat data were analyzed in conjunction with continuous stream discharge measurements and quarterly water-quality samples collected at each site to examine trends of aquatic biological communities in the FCB.

\section{Description of Study Area}

The FCB encompasses the study area, and the FCB and the sites included in this report were previously described in detail by others (Edelman and others, 2002; Mau and others, 2007; Zuellig and others, 2008). In general, the FCB encompasses approximately 926 square miles in southcentral Colorado draining the eastern slope of the Rocky Mountains (fig. 1). Elevation ranges from 4,700 feet (ft) at the confluence of Fountain Creek with the Arkansas River to 14,109 $\mathrm{ft}$ at the summit of Pikes Peak. Fountain and Monument Creeks are the two main drainages and are located in the transition of two distinctive physiographic landforms: the Front Range of the southern Rocky Mountains and the Colorado Piedmont (Hansen and others, 1982). These landforms correspond to two Level III ecoregions, the Southern Rockies and the Southwestern Tablelands (Omernik, 1987). However, the sites included in this study were restricted to the Southwestern Tablelands (fig. 1). Site elevations ranged from 4,705 to 6,270 ft (referenced to North American Vertical Datum of 1988) and drainage areas ranged from 65.6 to 926 square miles (table 1).

\section{Study Methods}

Daily streamflow, annual habitat and invertebrate, and quarterly water-chemistry data were collected at 10 sites in the FCB from 2003 to 2016 (fig. 1). Fish data were collected annually at nine sites from 2003 to 2016 and at one site (site 7) from 2007 to 2016 . The generalized analysis collectively consisted of the Kendall-tau test for trends (Lorenz, 2016), the Pearson correlation test (Harrell and others, 2017), and linear regression (R Development Core Team, 2016). For this analysis, a parametric correlation test was used which allowed a linear regression approach and the extraction of residuals from the regression. The generalized approach was to test for monotonic trends in fish and invertebrate community metrics (hereafter referred to as "biological metrics") at each site, while accounting for selected environmental factors that may potentially mask or possibly explain significant trends (fig. 2).

\section{Data Collection and Processing}

Invertebrates and fish were sampled each year during base-flow conditions (that is, the time of year when streamflow is usually dominated by groundwater seepage) in
September, October, and (or) November. Streamflow was measured continuously at these sites, and selected waterchemistry data were collected at various frequencies annually during the study period. Methods used to collect the data addressed in this report are briefly described in the subsections below. See Mau and others (2007) and Zuellig and others $(2008,2014)$ and the citations within those three reports for further explanation.

\section{Hydrology}

Streamflow was measured at streamgages at the 10 sampling stations that are identified by USGS station number in table 1 . Daily mean discharge was used to compute metrics of antecedent streamflow for evaluation with habitat, fish, and invertebrate sampling data.

\section{Streamflow Measurements}

Instantaneous stream discharge (in cubic foot per second) and daily mean discharge (in cubic foot per second) were measured and computed in accordance with standard USGS procedures described by Rantz and others (1982). Measurements of instantaneous stream discharge were made at all 10 sampling stations (table 1) throughout the study period at cross sections in the vicinity of the USGS streamgages that had the most even distribution of streamflow. These stream discharge measurements were used to develop site-specific, stage-discharge relations (rating curves) that were then used to compute continuous discharge data from the stage record associated with the 10 USGS surface-water gages. Daily mean and instantaneous streamflow mentioned in this report can be obtained through the USGS National Water Information System at https://doi.org/10.5066/F7P55KJN (search by USGS station number, table 1).

\section{Antecedent Streamflow}

The daily mean value of streamflow was used to calculate several measurements (metrics) of the streamflow that preceded fish and invertebrate sampling dates (see "Hydrology and Day of the Year" section of this report). These metrics represent both short- and long-term measures of streamflow conditions prior to sampling each year at each site.

\section{Habitat}

Habitat variables were measured after biological sampling each year (within 15-80 days) along a predefined reach defined as 20 times the mean wetted width (range from 100 to 300 meters [m] [328 to $984 \mathrm{ft}$ ]). Bank height and percent riffle were estimated following the methods of Meador and others (1993); multiple measurements were made at six equally spaced transects along the reach perpendicular to streamflow. Streambed and bank substrate were characterized from a pebble count made at approximately 100 points along the stream reach as suggested by Wolman (1954). 


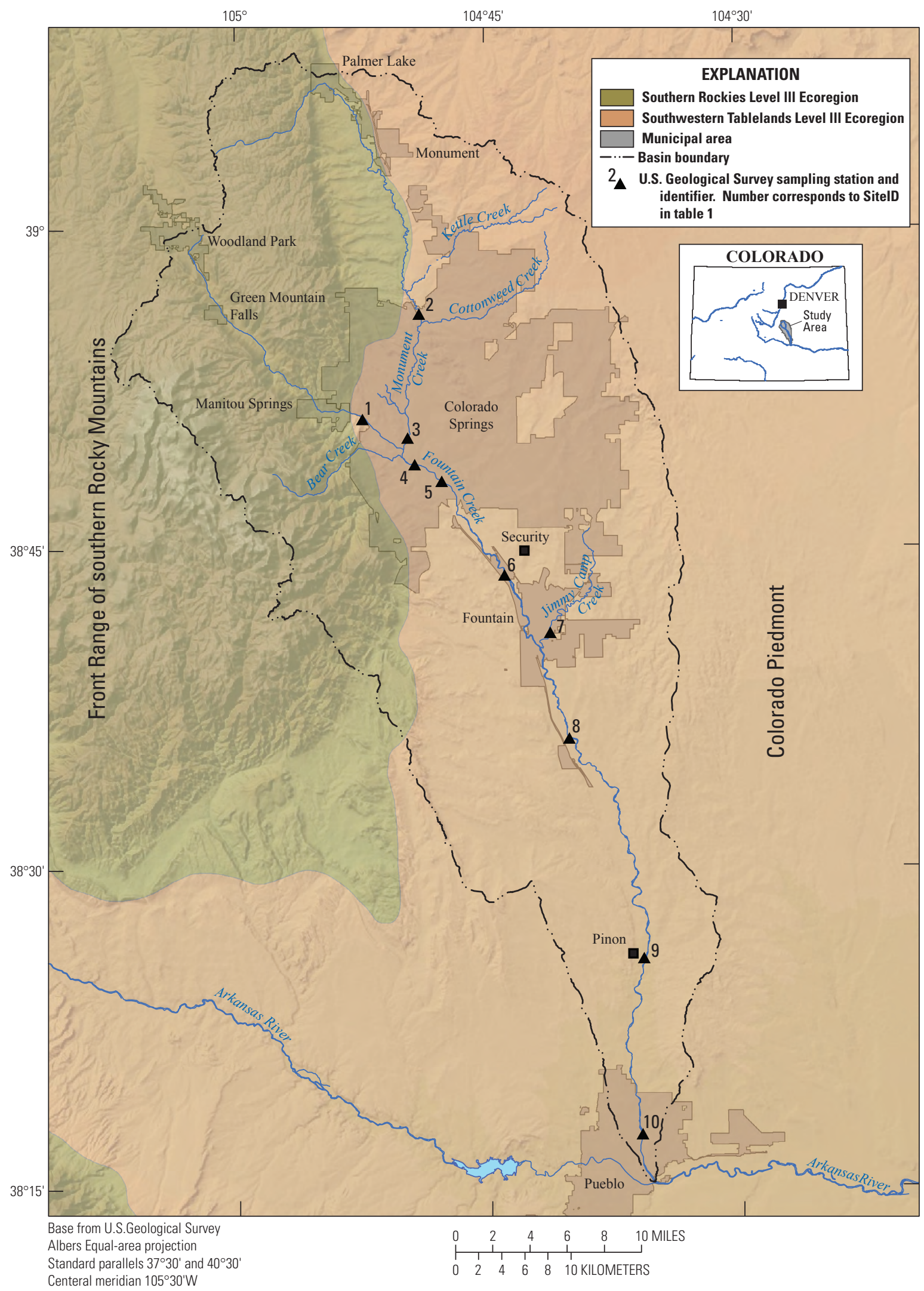

Figure 1. Map showing locations of sampling sites in the Fountain Creek Basin, Colorado, 2003-2016. 


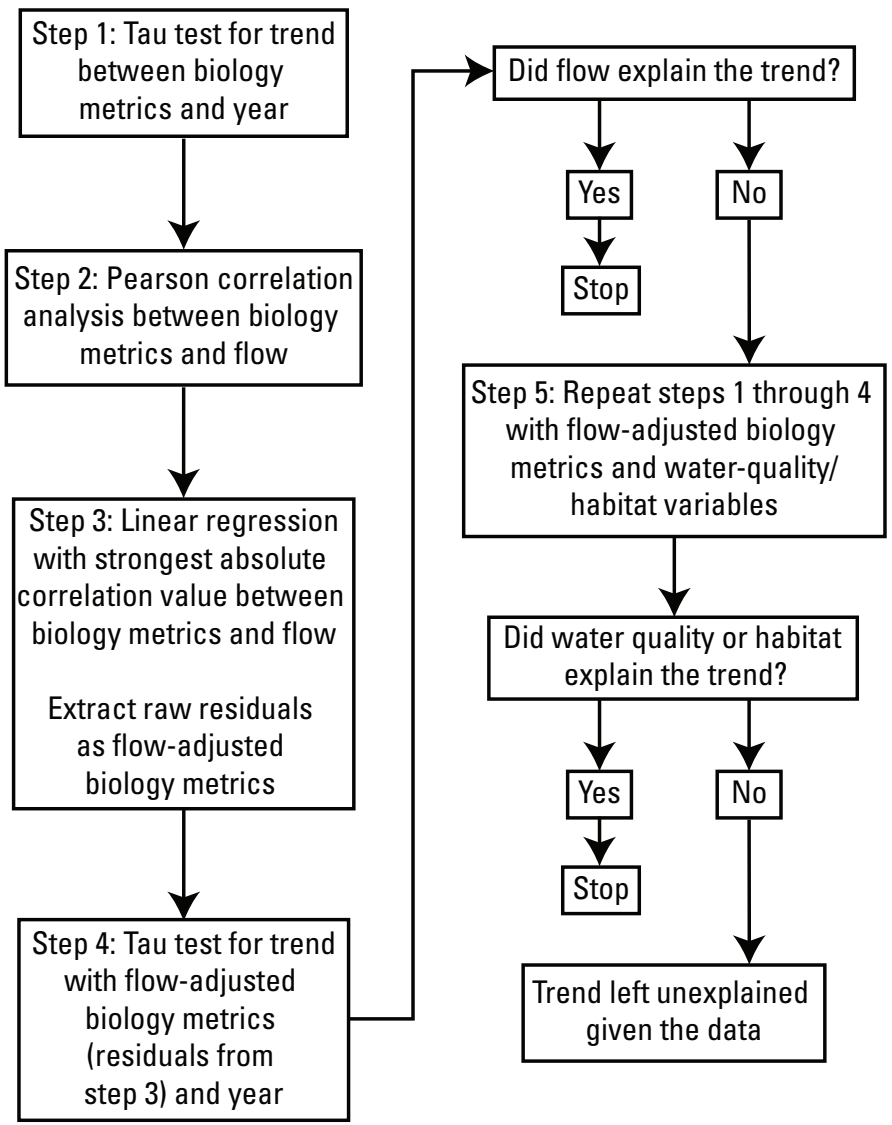

Figure 2. General flow diagram illustrating data analysis steps for detecting and explaining trends in invertebrate and fish communities, Fountain Creek Basin, Colorado, 2003-2016.

\section{Water Chemistry}

All samples were collected, processed, and preserved in the field according to standard methods described in the USGS National Field Manual (USGS, variously dated). Samples were analyzed at the USGS National Water Quality Laboratory in Lakewood, Colorado. See Mau and others (2007) for detailed information concerning water-chemistry collection methods and interpretation of water-chemistry data, as well as information concerning quality assurance/quality control. For the analyses described in this report, three water chemistry parameters were included: temperature, specific conductance, and nitrogen (dissolved nitrite plus nitrate [DNO23]) and total nitrogen).

\section{Invertebrates}

At each site, qualitative multihabitat samples were collected annually from all available habitat types within the stream reach encompassing 1 hour of sampling (Cuffney and others, 1993). Different habitat types were identified, their contributing area of the reach in relative occurrence was calculated, and the matching fraction of 1 hour was spent sampling each associated habitat type. See Zuellig and others (2014) for a detailed explanation concerning habitat types, collection methods, and sample processing for invertebrate qualitative multihabitat samples.

\section{Fish}

Fish community data were collected annually at 10 sites in mid-September to late October during base-flow conditions. All sites, which were wadable at the time of sampling, were electrofished in an upstream direction with a single pass (Pusey and others, 1998) ordinarily using two Smith-Root pulsed direct current backpack electroshockers (models 12B POW, 15D POW, and LR24). A concerted effort was made to sample all available habitats. After capture, fish were maintained in aerated live wells. Fish were identified (table 2), enumerated, and measured (total length) in the field, tallied in the nearest 2 centimeters ( $\mathrm{cm} ; 0.79$ inches) length class, observed for anomalies, and released.

\section{Data Processing}

Several steps were taken before these data were analyzed. This included reconciling invertebrate taxa names to meet the most current standards, phylogenic relationships, and taxonomic nomenclature. Fish that were not identified to species were removed. These finalized biological datasets were then used to calculate metrics representing selected attributes of invertebrate and fish communities. Streamflow data were used to calculate metrics of antecedent streamflow. Water-quality and habitat data for the date closest to the biological sampling event were selected for use in the trend analysis.

\section{Hydrology and Day of the Year}

Hydrologic metrics representing antecedent and annual peak streamflow were calculated along with the day of the year (DOY) a sample was collected. Selected hydrologic metrics were calculated to help describe conditions antecedent to each sample date, as was the day of the year that each sample was collected. These variables were used to help account for interannual variability in endpoint values that resulted from differences in year-to-year conditions prior to sampling (table 3 ).

\section{Day of the Year}

It is often assumed that interannual variability in endpoint values is reduced by consistently sampling within the same index period (range of dates) each year (Cuffney and others, 1993; Moulton and others, 2000). Although this is a logical way to sample for trend studies, year-to-year conditions within the same index period vary widely. In a variance-components study of National Water-Quality Assessment Project 
Table 2. Fish species collected by the U.S. Geological Survey and Colorado Parks and Wildlife in the Fountain Creek Basin, Colorado, 2003-2016.

[N, native; I, introduced; NA, not applicable; $\mathrm{x}$, genetic cross; <, less than; mm, millimeter]

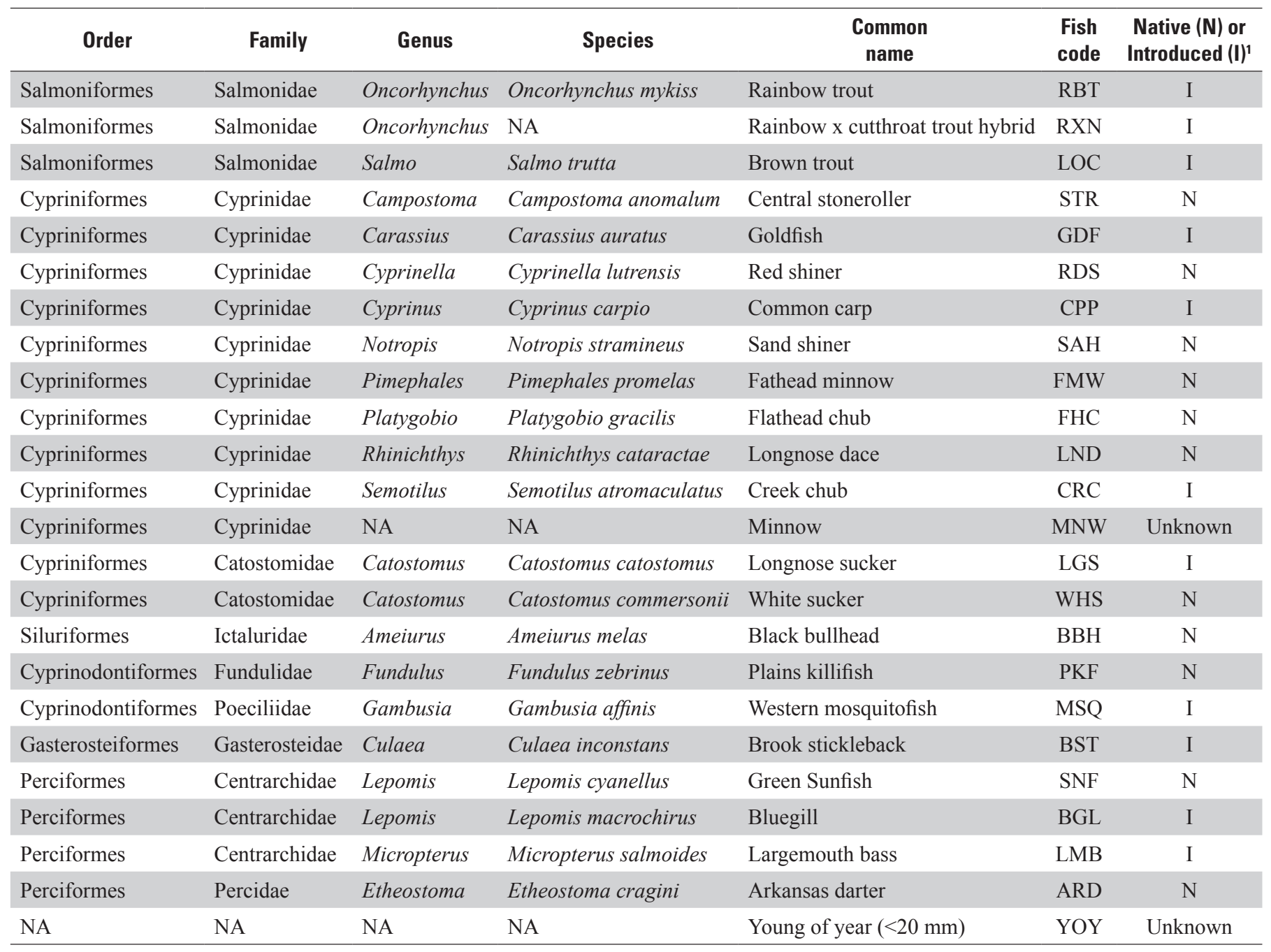

${ }^{1}$ From Fausch and Bestgen, 1997.

invertebrate data, Gurtz and others (2013) found the timing of data collection can explain more than 60 percent of variances in some endpoint values; therefore, the DOY (table 3) when each sample was collected was identified to help account for any influence of sample timing, in addition to the influence of antecedent streamflow conditions, on endpoint variability. For each site, the DOY was determined by normalizing (that is, dividing) the DOY when each sample was collected by the average DOY for the site when samples were collected over the trend period. DOY values less than 1 indicated a sample was collected earlier than average in the index period, likewise values greater than 1 indicated sample collection was later than average.

\section{Antecedent Streamflow}

Average daily streamflow and the coefficient of variation of daily streamflow were calculated for 30 and 240 days antecedent to each sample date. These selected antecedent periods were intended to capture site-specific conditions that may influence year-to-year differences in fish and invertebrate endpoints. For example, higher than average streamflow occurring 30 days prior to sampling may influence the habitat that is available or accessible for sampling in a given year. All values were normalized by the average value calculated for a site during the trend period. For example, if the sample date was September 30, the 30-day average daily streamflow (avg30) for 30 days prior to the sample was calculated for September 1 through September 30. This value was then divided by the average of daily streamflow values from September 1 through September 30 of each year from 2003 to 2016. 
Table 3. Environmental variables used to detect monotonic trends in invertebrate and fish biological community structure at selected sites in the Fountain Creek Basin, Colorado, 2003-2016.

\begin{tabular}{|c|c|}
\hline Code & Environmental variable and unit \\
\hline \multicolumn{2}{|r|}{ Streamflow variables } \\
\hline $\operatorname{avg} 30$ & Normalized average daily flow value of the 30 days prior to sampling \\
\hline $\operatorname{cv} 30$ & Normalized daily flow coefficient of variation of the 30 days prior to sampling \\
\hline cv240 & Normalized daily flow coefficient of variation of the 240 days prior to sampling \\
\hline \multicolumn{2}{|r|}{ Habitat variables } \\
\hline \multicolumn{2}{|r|}{ Quantitative variables } \\
\hline $\operatorname{maxBH}{ }^{1}$ & Maximum bank height (meters) \\
\hline pcob & Percent occurrence of cobble from Wolman pebble count (percentage) \\
\hline avgTemp & Mean water temperature (degrees Celsius) \\
\hline $\mathrm{SC}$ & Specific conductance (microsiemens per centimeter at 25 degrees Celsius) \\
\hline
\end{tabular}

\section{Peak Streamflow}

To quantify ecologically relevant daily maximum streamflow, a threshold of 20 cubic meters per second (706.29 cubic feet per second) was used as proposed by Haworth and Bestgen (2017) in a study of age-0 FHC (that is, individual FHC in their first year of life) growth and survival in Fountain Creek. Streamflow exceeding this threshold was shown to decrease growth, and therefore, survival of age- 0 FHC because better thermal conditions exist at streamflow levels below the 706.29 cubic feet per second threshold. Thermal conditions present during low or stable streamflow conditions promote better FHC growth resulting in increased survival and recruitment of age-0 FHC (Haworth and Bestgen, 2016, 2017). The number of daily maximum streamflow values that equaled or exceeded this value from May through August was found to be important to the growth and survival of age-0 FHC. To apply this value at other streamgages in the FCB, the percentile of this streamflow value was determined at site 8 , the same study site used by Haworth and Bestgen (2017). This threshold value was the 98th percentile of daily average streamflow values from 2003 to 2016. The streamflow value was then calculated that was equal to the 98th percentile at site 6 , which was 619.94 cubic feet per second. Channel morphology, which varies between sites, dictates how a volume of water is distributed in a channel, so the 98th percentile as the streamflow threshold was applied because the relative magnitude of this streamflow value (that is, the flow percentile) is the most comparable among sites. This peak streamflow metric was only calculated at sites 6 and 8 because they were the only sites that harbored consistent FHC populations over the study period. For each year at these two USGS streamgages, the number of daily maximum streamflow occurrences (hereafter referred to as "peak flow days") was summed from May through August representing the number of peak streamflows above the threshold each year.

\section{Habitat Samples}

Three habitat metrics were selected from a possible 47 for analysis based on previous studies that identified important habitat variables that were shown to explain variation in FCB biological communities (Zuellig and others, 2010). These three metrics are (1) percent of substrate that is cobble (that is, 64-256 millimeters in size), (2) maximum bank height (maxBH, in meters), and lower bank capacity (Rapid Bioassessment Protocol; Barbour and others, 1997). The percent cobble metric was calculated following USGS National Water Quality Assessment protocol (Meador and others, 1993); the total of all the pebbles greater than 64 millimeters and less than 256 millimeters in size were divided by the total number of pebbles counted. The maxBH was determined by the greatest value of bank height measured each year for every site. The lower bank capacity values were scored as a secondary Rapid Bioassessment Protocol attribute and given a value on a scale from 0 to 15 . 


\section{Invertebrate Samples}

Invertebrates were identified in the laboratory to the lowest practical taxonomic resolution, which was mostly genus or species (mollusks, crustaceans, and insects), but also included family, phylum, or class (aquatic worms, flatworms, and nematodes). Names were examined for cases where changes in taxonomic classification occurred during the study period. In such cases, names were harmonized to help alleviate any bias from changes in taxonomy. Ambiguous taxa were resolved by keeping only those taxa that were unique within each sample. This approach allows ambiguous taxa across the dataset, but preserves taxa richness within each sample. Finally, counts were reduced to zeros and ones to indicate if a taxa was present (1) or absent (0) in a sample.

\section{Invertebrate Metrics}

Invertebrate richness (InvRich); percentage of mayfly, stonefly, and caddisfly richness (InvpEPTrich); and BrayCurtis Similarity (InvLTsim) were calculated for each invertebrate sample (table 4). InvRich was calculated as the sum of the number of different invertebrate taxa found in a sample. InvpEPTrich was calculated as the percentage of taxa richness comprised of individuals belonging to the orders Ephemeroptera (mayflies), Plecoptera (stoneflies), and Trichoptera (caddisflies). InvLTsim was calculated as the Invertebrate Bray-Curtis Similarity value (Bray and Curtis, 1957) between each year and the start year in the trend period (year 1 with 2 , year 1 with 3 , year 1 with 4 , year 1 with 5 , and so on). This measure evaluates changes relative to the start year.

\section{Fish Samples}

The analysis of fish sample data was restricted to fish that were identified to species (table 2). Unknown young-ofthe-year fish, general minnows (Cyprinidae), and rainbow trout (Oncorhynchus mykiss) x cutthroat trout (Oncorhynchus clarki) hybrids were excluded. The total counts for each species from the annual one-pass electrofishing were used for the trend analysis.

\section{Fish Metrics}

The catch per unit effort (CPUE) for fish (FishCPUE) was calculated for each fish species to allow for comparison among years and sites. The number of nets used at a site for a given year was multiplied by the surface acres of stream that were sampled (length of electrofishing pass times stream wetted width) and the total number of each fish species caught was divided by that measure to calculate the FishCPUE of each species at every site for all the years sampled. The fish species richness metric (FishRich) was used to examine the community composition of fish species. FishRich was calculated by summing the total number of fish species that were present at a site. The FishLTsim metric of fish community composition also was calculated, which represents how different or similar community composition is based on both taxa number and abundance (Bray-Curtis Similarity value; Bray and Curtis, 1957). The FishLTsim metric, which is the value between each year and the start year in the trend period (year 1 with 2, year 1 with 3 , year 1 with 4 , year 1 with 5 , and so on), evaluates changes in community similarity relative to the start

Table 4. Metric descriptions for invertebrate and fish communities calculated for monotonic trend assessment in the Fountain Creek Basin, Colorado, 2003-2016.

[CPUE, catch per unit effort]

\begin{tabular}{ll}
\hline \multicolumn{1}{c}{ Code } & \multicolumn{1}{c}{ Metric } \\
\hline InvRich & $\begin{array}{l}\text { The number of unique invertebrate taxa in a sample } \\
\text { InvpEPTrich } \\
\text { Percent invertebrate taxa richness comprised of individuals belonging to the orders Ephemeroptera (mayflies), Plecoptera } \\
\text { (stoneflies), and Trichoptera (caddisflies) } \\
\text { Invertebrate Bray-Curtis Similarity value between each year and the start year in the trend period }\end{array}$ \\
\hline FishRich & The number of different fish species in a sample \\
FishLTsim & Fish Bray-Curtis Similarity value between each year and the start year in the trend period \\
FishCPUE & The number of fish captured divided by the product of surface acres sampled and the number of nets \\
FHC_CPUE & The CPUE calculated for flathead chub \\
CRC_CPUE & The CPUE calculated for creek chub \\
WHS_CPUE & The CPUE calculated for white sucker \\
ARD_CPUE & The CPUE calculated for Arkansas darter \\
\hline
\end{tabular}


year. Individual species counts were fourth-root transformed before FishLTsim values were calculated. Fourth-root transformation downweights the contribution of highly abundant species while boosting the influence of those with midrange and lower abundances (Clarke and Warwick, 2001).

\section{Selected Species}

Trend analyses were also performed on CPUE of a four-species subset that included two species of conservation concern (FHC and ARD) and two ubiquitous species (the nonnative creek chub [Semotilus atromaculatus; CRC] and the native white sucker [Catostomus commersonii; WHS]; table 2). These analyses were performed for the species of conservation concern (Rahel and Thel, 2004; Colorado Parks and Wildlife, 2017) only at sites where they were prevalent throughout the time series of the dataset (sites 6 and 8-FHC; site 7-ARD). The sites selected for these species of conservation concern were only those where the most robust populations of FHC and ARD were found. While this includes the only site where ARD were found every year, the FHC sites are the top two in consistent abundance of the eight sites where FHC have been captured at one time within the FCB. All the sites with no years of zero catch were used in the trend analysis for CRC (sites 2-8) and WHS (sites 2-10).

An additional analysis of size classes for $\mathrm{FHC}$ was also performed. In this analysis, the CPUE for FHC of less than or equal to $6 \mathrm{~cm}$ total length was used to represent age- 0 individuals. Age and growth analysis of FHC in FCB near site 8 found that individuals less than or equal to $6 \mathrm{~cm}$ total length in the fall were likely hatched that year and are of the age- 0 year class (Haworth and Bestgen, 2016). These annual estimates of age- $0 \mathrm{FHC}$ were compared to patterns of peak flow days (in the sense of Haworth and Bestgen, 2017; see the discussion on peak streamflow).

\section{Data Analysis}

The purpose of this study was to describe and explain trends in invertebrate and fish communities at 10 sites in the FCB for 2003-2016. This data analysis is aimed at describing these community trends across the entire FCB capitalizing on the time series of data available across 10 sites in the study area. This approach provides the power to assess these trends beyond just site-specific changes and characterize the patterns in time of invertebrate and fish communities within FCB. The analysis collectively consisted of the Kendall-tau test for trends (Lorenz, 2016), the Pearson correlation test (Harrell and others, 2017), and linear regression (R Development Core Team, 2016). The generalized approach was to test for monotonic trends in invertebrate and fish community metrics (referred to as "biological metrics" in this report) at each site, while accounting for selected environmental factors that may potentially mask or possibly explain a significant trend (fig. 2). First, Kendall-tau test for trends (Lorenz, 2016) was used to determine if any biological metrics were increasing or decreasing over the trend period at each site. Second, Pearson correlation analysis (Harrell and others, 2017) was used to identify which environmental variable had the strongest correlation (highest absolute $r$ value) with each biological metric. Third, the raw residuals were extracted from a simple linear regression equation (R Development Core Team, 2016) of each biological metric paired with the strongest correlated environmental variable for each site. The raw residuals represented the biological metric after accounting for the presumed confounding environmental variable. Fourth, Kendall-tau test for trends was used again to determine if the adjusted biological metrics (raw residuals) were increasing or decreasing over the trend period at each site. Significant trend results were identified if the p-value (probability) associated with the Kendall-tau test for trends was less than or equal to 0.1 .

Results of the four steps described above were interpreted in one of several ways. For a given site and biological metric, if a significant trend was detected before adjustment but was absent after adjustment, the environmental variable was said to describe the initial trend. In these cases, the environmental variable was actually trending in the same way as the biological metric. On the other hand, when a trend was not detected before adjustment but was present after adjustment, the variability in the environmental variable was actually preventing the statistical detection (termed masking) of the underlying trend in the biological metric. In these cases, once the variability in the biological metric associated with the environmental variable was removed, the trend was revealed and statistically distinguishable from zero. There also were cases when there was a trend both before and after adjustment. In these cases, antecedent streamflow or DOY was unable to describe the trend; therefore, habitat and water quality were explored as potential explanatory variables by repeating steps 1 through 4 (step 5, fig. 2) on the residuals from step 3 (fig. 2) using the habitat and water-quality data (step 5, fig. 2).

All trend results for the streamflow-adjusted analysis (steps 1-4) are shown in figure 2. The direction and magnitude of trends are reported as the percentage of change between the observed value in the first year of the dataset and the predicted value from the regression equation (step 3 ) for 2016 (that is, the last year in the dataset). However, because predicted values for this calculation were used, some changes are less than -100 percent, which is not possible for biological population data, so values less than or equal to -100 percent are presented as " $-100 \%$ *" in results and tables of this report. The results for step 5 are shown for the sites and metrics where there was still a trend after being adjusted for streamflow. The results for the trends analyzed for water-quality and habitat variables are reported in percentage change; however, the initial value for this change is the streamflow-adjusted residual value for the first year from step 4 . These trend results are presented in the same format but with different tables: one set of tables for the biological metrics (fish and invertebrates; tables 5 and 6) and a second set of tables for the individual fish species (CRC, FHC, WHS, ARD; tables 7 and 8). 


\section{Changes in Biological Communities of Fountain Creek Basin}

Trends in the biological metrics were detected at 8 of the 10 sites sampled throughout the FCB. Most of these trends were decreasing even after being adjusted for antecedent streamflow measures (fig. 3, table 5). Of the 60 trends tested, 19 (1 increasing and 18 decreasing) were found to be significant (that is, having a trend before being adjusted for streamflow and labeled as Before or BeforeAfter; table 5). After adjusting for streamflow, 16 (1 increasing and 15 decreasing; labeled as BeforeAfter or After) trends were significant and the most frequently identified explanatory antecedent streamflow variable was the 30-day daily streamflow coefficient of variation for 30 days prior to sample collection (cv30), which

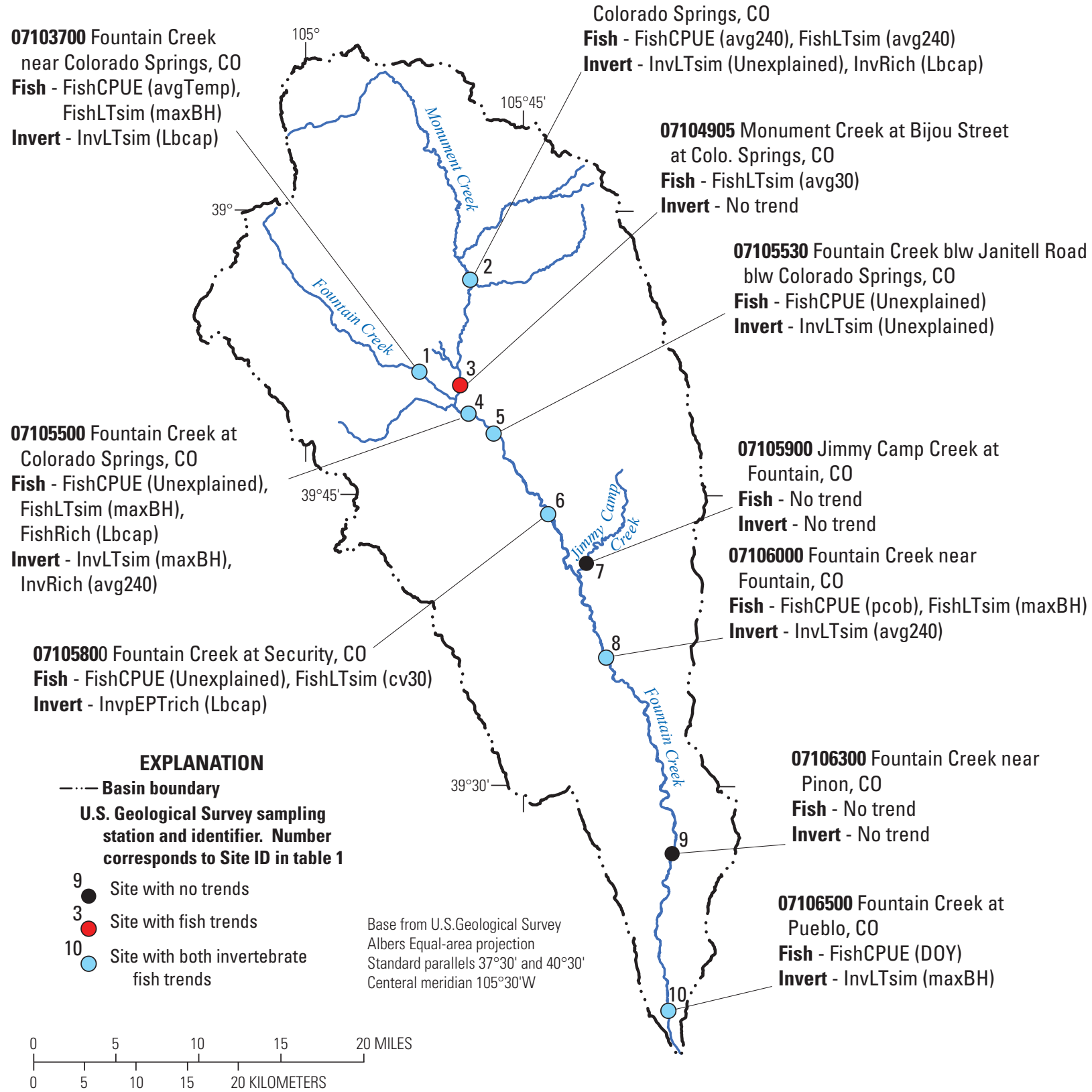

Figure 3. Map showing the spatial distribution of trends in fish and invertebrate metrics in the Fountain Creek Basin, Colorado, 2003-2016. Environmental variables that explained a trend in fish or invertebrate metrics are presented parenthetically (data from table 5 for explanatory streamflow variables or table 6 for explanatory habitat or water-quality variables). Site labels correspond to site identific ation numbers in table 1, variables in parenthesis are defined in table 3 , and metric descriptions are provided in table 4. (Invert, invertebrates; abv, above; blw, below) 
Table 5. Monotonic trends in invertebrate and fish metrics explained by antecedent streamflow variables in the Fountain Creek Basin, Colorado, $2003-2016$.

[Italicized and bolded text indicates a significant trend. ID, identification; USGS, U.S. Geological Survey; y, biological endpoint being assessed for trend; tauO, test statistic Kendall's tau associated with the unadjusted data; pO, p value associated with tauO; slopeO, median change in metric units per year calculated as Sen Slope (Sen, 1968); interceptO, intercept computed from the median of the biological metric and time, also known as the Conover method (Conover, 1999); firstPred, first years predicted value calculated as slopeOxfirstYear+interceptO; Per.ChangeO, percentage change of the trend period for the unadjusted response variable calculated as 100x((slopeOx(lastYear-firstYear))/firstPred; $x$, environmental variable most strongly correlated with the associated biological metric; rCorr, Pearson's correlation coefficient between $\mathrm{x}$ and y; pCorr, p value associated with rCorr; tauR, test statistic Kendall's tau associated with the data adjusted for x; pR, p value associated with tauR; slopeR, median change in residual units per year calculated as Sen Slope (Sen, 1968); interceptR, intercept computed from the median of the residuals (the biological metric adjusted for x) and time, also known as the Conover method (Conover, 1999); Per.ChangeR, percentage change over trend period after the response variable has been adjusted for $\mathrm{x}$ calculated as 100x((slopeRx(lastYear-firstYear))/firstPred; Results, indicates what types of trends were found in relation to streamflow adjustment (that is, Before [prior to streamflow adjustment], BeforeAfter [prior to and after streamflow adjustment], After [after streamflow adjustment], or NoTrend)]

\begin{tabular}{|c|c|c|c|c|c|c|c|c|c|c|c|c|c|c|c|c|c|}
\hline $\begin{array}{l}\text { Site } \\
\text { ID }^{\mathrm{a}}\end{array}$ & $\begin{array}{l}\text { USGS } \\
\text { station } \\
\text { number }\end{array}$ & $y^{b}$ & tau0 & p0 & slope0 & intercept0 & firstPred & $\begin{array}{c}\text { Per. } \\
\text { Change0 }\end{array}$ & $\mathbf{x}^{\mathbf{c}}$ & rCorr & pCorr & tauR & $\mathrm{pR}$ & slopeR & interceptR & $\begin{array}{c}\text { Per. } \\
\text { ChangeR }\end{array}$ & Results \\
\hline 1 & 07103700 & FishCPUE & -0.313 & .137 & -5.207 & $0,507.947$ & 77.883 & -86.917 & avg30 & -0.441 & 0.115 & -0.341 & 0.101 & -4.514 & $9,066.507$ & -75.341 & After \\
\hline 1 & 07103700 & FishLTsim & -0.248 & 0.269 & -0.016 & 33.836 & 0.83 & -23.804 & DOY & -0.532 & 0.061 & -0.359 & 0.1 & -0.025 & 50.775 & -36.49 & After \\
\hline 1 & 07103700 & FishRich & -0.172 & 0.477 & 0 & 1 & 1 & 0 & DOY & -0.525 & 0.054 & -0.156 & 0.475 & -0.033 & 65.701 & & NoTrend \\
\hline 1 & 07103700 & InvLTsim & -0.623 & 0.004 & -0.013 & 27.226 & 0.492 & -32.551 & $c v 240$ & -0.422 & 0.15 & -0.513 & 0.017 & -0.012 & 24.317 & -29.538 & BeforeAfter \\
\hline 1 & 07103700 & InvpEPTrich & -0.233 & 0.272 & -0.004 & 8.597 & 0.251 & -21.559 & DOY & -0.481 & 0.082 & -0.165 & 0.443 & -0.002 & 4.762 & & NoTrend \\
\hline 1 & 07103700 & InvRich & -0.216 & 0.319 & -0.3 & 628.85 & 27.95 & -13.953 & $\operatorname{avg} 240$ & -0.377 & 0.184 & -0.121 & 0.584 & -0.11 & 219.111 & & NoTrend \\
\hline 2 & 07103970 & FishCPUE & -0.516 & 0.012 & -38.869 & $78,410.715$ & 555.179 & -91.016 & $\operatorname{avg} 240$ & -0.511 & 0.062 & -0.275 & 0.189 & -22.234 & $44,638.599$ & -52.063 & Before \\
\hline 2 & 07103970 & FishLTsim & -0.41 & 0.059 & -0.011 & 22.34 & 0.795 & -16.237 & $\operatorname{avg} 240$ & -0.629 & 0.021 & -0.179 & 0.428 & -0.004 & 8.993 & -6.746 & Before \\
\hline 2 & 07103970 & FishRich & 0.096 & 0.716 & 0 & 5 & 5 & 0 & avg240 & 0.651 & 0.012 & -0.165 & 0.443 & -0.042 & 84.611 & & NoTrend \\
\hline 2 & 07103970 & InvLTsim & -0.564 & 0.009 & -0.013 & 27.185 & 0.603 & -26.412 & $\operatorname{avg} 240$ & -0.675 & 0.011 & -0.436 & 0.044 & -0.01 & 20.244 & -20.049 & BeforeAfter \\
\hline 2 & 07103970 & InvpEPTrich & -0.022 & 0.956 & -0.001 & 1.492 & 0.257 & & avg240 & -0.292 & 0.312 & 0.055 & 0.827 & 0.001 & -1.629 & & NoTrend \\
\hline 2 & 07103970 & InvRich & 0.265 & 0.207 & 0.875 & $-1,718.812$ & 33.812 & 33.641 & $c v 30$ & -0.391 & 0.167 & 0.385 & 0.063 & 0.974 & $-1,955.699$ & 37.438 & After \\
\hline 3 & 07104905 & FishCPUE & -0.011 & 1 & -0.004 & 86.23 & 77.504 & -0.073 & $\operatorname{cv} 30$ & 0.831 & 0 & 0.297 & 0.155 & 3.093 & $-6,200.689$ & & NoTrend \\
\hline 3 & 07104905 & FishLTsim & -0.359 & 0.1 & -0.007 & 13.76 & 0.699 & -11.185 & $\operatorname{avg} 30$ & -0.407 & 0.168 & -0.256 & 0.246 & -0.006 & 12.603 & -10.766 & Before \\
\hline 3 & 07104905 & FishRich & -0.145 & 0.55 & 0 & 6 & 6 & 0 & DOY & -0.381 & 0.179 & -0.101 & 0.659 & -0.005 & 10.33 & & NoTrend \\
\hline 3 & 07104905 & InvLTsim & -0.205 & 0.36 & -0.006 & 13.368 & 0.46 & -16.815 & DOY & 0.294 & 0.329 & -0.179 & 0.428 & -0.005 & 10.966 & & NoTrend \\
\hline 3 & 07104905 & InvpEPTrich & 0.077 & 0.743 & 0.002 & -3.935 & 0.183 & 14.572 & cv240 & -0.47 & 0.09 & 0.165 & 0.443 & 0.004 & -7.054 & & NoTrend \\
\hline 3 & 07104905 & InvRich & -0.057 & 0.824 & 0 & 32 & 32 & 0 & & & 0.526 & & & -0.13 & & & \\
\hline 4 & 07105500 & FishCPUE & -0.451 & 0.029 & -6.799 & $13,744.749$ & 125.862 & -70.228 & $c v 30$ & 0.871 & 0 & -0.385 & 0.063 & -4.506 & $9,066.948$ & -46.541 & BeforeAfter \\
\hline 4 & 07105500 & FishLTsim & -0.718 & 0.001 & -0.035 & 70.353 & 0.833 & -49.985 & $\operatorname{avg} 240$ & -0.485 & 0.093 & -0.462 & 0.033 & -0.03 & 59.654 & -42.734 & BeforeAfter \\
\hline 4 & 07105500 & FishRich & -0.451 & 0.038 & -0.2 & 407.4 & 6.8 & -38.235 & $c v 30$ & 0.833 & 0 & -0.451 & 0.029 & -0.111 & 223.831 & -21.299 & BeforeAfter \\
\hline 4 & 07105500 & InvLTsim & -0.426 & 0.05 & -0.011 & 23.416 & 0.51 & -26.908 & DOY & 0.399 & 0.177 & -0.538 & 0.012 & -0.01 & 19.412 & -22.749 & BeforeAfter \\
\hline 4 & 07105500 & InvpEPTrich & -0.056 & 0.825 & -0.001 & 1.636 & 0.171 & -5.544 & $\operatorname{cv} 240$ & -0.324 & 0.258 & -0.011 & 1 & -0.001 & 1.034 & & NoTrend \\
\hline 4 & 07105500 & InvRich & 0.426 & 0.045 & 0.444 & -857.611 & 32.611 & 17.717 & $\operatorname{avg} 240$ & 0.261 & 0.368 & 0.297 & 0.155 & 0.408 & -819.945 & 16.267 & Before \\
\hline 5 & 07105530 & FishCPUE & -0.495 & 0.016 & -9.743 & $19,650.145$ & 134.256 & -94.345 & avg240 & -0.448 & 0.108 & -0.363 & 0.08 & -4.907 & $9,825.372$ & -47.515 & BeforeAfter \\
\hline 5 & 07105530 & FishLTsim & -0.051 & 0.855 & -0.003 & 5.978 & 0.619 & -5.181 & $\operatorname{avg} 240$ & -0.597 & 0.031 & 0.077 & 0.76 & 0.003 & -5.928 & & NoTrend \\
\hline 5 & 07105530 & FishRich & 0.341 & 0.145 & 0 & 6.5 & 6.5 & 0 & DOY & 0.401 & 0.156 & 0.265 & 0.207 & 0.049 & -98.244 & & NoTrend \\
\hline 5 & 07105530 & InvLTsim & -0.426 & 0.05 & -0.009 & 18.163 & 0.569 & -18.522 & $c v 240$ & -0.408 & 0.167 & -0.462 & 0.033 & -0.007 & 13.721 & -14.396 & BeforeAfter \\
\hline 5 & 07105530 & InvpEPTrich & -0.077 & 0.743 & -0.002 & 3.98 & 0.187 & -13.184 & cv240 & 0.59 & 0.026 & -0.055 & 0.827 & -0.003 & 5.161 & & NoTrend \\
\hline 5 & 07105530 & InvRich & 0.056 & 0.826 & 0.111 & -193.278 & 29.278 & 4.934 & DOY & -0.496 & 0.071 & -0.011 & 1 & -0.018 & 36.992 & & NoTrend \\
\hline 6 & 07105800 & FishCPUE & -0.56 & 0.006 & -17.664 & $35,627.871$ & 247.094 & -92.932 & $c v 30$ & 0.553 & 0.04 & -0.407 & 0.049 & -12.093 & $24,269.115$ & -63.623 & BeforeAfter \\
\hline 6 & 07105800 & FishLTsim & -0.436 & 0.044 & -0.008 & 16.938 & 0.754 & -12.852 & $c v 30$ & 0.538 & 0.058 & -0.308 & 0.161 & -0.006 & 12.813 & -10.147 & Before \\
\hline
\end{tabular}


Table 5. Monotonic trends in invertebrate and fish metrics explained by antecedent streamflow variables in the Fountain Creek Basin, Colorado, 2003-2016.-Continued

[Italicized and bolded text indicates a significant trend. ID, identification; USGS, U.S. Geological Survey; y, biological endpoint being assessed for trend; tauO, test statistic Kendall's tau associated with the unadjusted data; pO, p value associated with tauO; slopeO, median change in metric units per year calculated as Sen Slope (Sen, 1968); interceptO, intercept computed from the median of the biological metric and time, also known as the Conover method (Conover, 1999); firstPred, first years predicted value calculated as slopeOxfirstYear+interceptO; Per.ChangeO, percentage change of the trend period for the unadjusted response variable calculated as 100x((slopeOx(lastYear-firstYear))/firstPred; $\mathrm{x}$, environmental variable most strongly correlated with the associated biological metric; rCorr, Pearson's correlation coefficient between $\mathrm{x}$ and $\mathrm{y}$; $\mathrm{pCorr}, \mathrm{p}$ value associated with rCorr; tauR, test statistic Kendall's tau associated with the data adjusted for $\mathrm{x} ; \mathrm{pR}$, $\mathrm{p}$ value associated with tauR; slopeR, median change in residual units per year calculated as Sen Slope (Sen, 1968); interceptR, intercept computed from the median of the residuals (the biological metric adjusted for x) and time, also known as the Conover method (Conover, 1999); Per.ChangeR, percentage change over trend period after the response variable has been adjusted for $\mathrm{x}$ calculated as 100x((slopeRx(lastYear-firstYear))/firstPred; Results, indicates what types of trends were found in relation to streamflow adjustment (that is, Before [prior to streamflow adjustment], BeforeAfter [prior to and after streamflow adjustment], After [after streamflow adjustment], or NoTrend)]

\begin{tabular}{|c|c|c|c|c|c|c|c|c|c|c|c|c|c|c|c|c|c|}
\hline $\begin{array}{l}\text { Site } \\
\text { ID }^{\mathrm{a}}\end{array}$ & $\begin{array}{c}\text { USGS } \\
\text { station } \\
\text { number }\end{array}$ & $y^{b}$ & tau0 & p0 & slope0 & intercept0 & firstPred & $\begin{array}{c}\text { Per. } \\
\text { Change0 }\end{array}$ & $x^{c}$ & rCorr & pCorr & tauR & pR & slopeR & interceptR & $\begin{array}{c}\text { Per. } \\
\text { ChangeR }\end{array}$ & Results \\
\hline 6 & 07105800 & FishRich & 0.144 & .576 & 0 & 7 & 7 & 0 & DOY & 0.495 & 072 & 0.088 & 0.701 & 0.016 & -33 & & NoTrend \\
\hline 6 & 07105800 & InvLTsim & -0.308 & 0.161 & -0.01 & 19.692 & 0.528 & -21.736 & cv240 & -0.739 & .004 & -0.154 & .502 & -0.003 & 6.993 & & NoTrend \\
\hline 6 & 07105800 & InvpEPTrich & -0.099 & 0.661 & -0.002 & 3.968 & 0.205 & -11.925 & $c v 240$ & 0.488 & 0.077 & -0.385 & 0.063 & -0.005 & 9.373 & -29.578 & After \\
\hline 6 & 07105800 & InvRich & -0.078 & 0.742 & -0.167 & 361.417 & 27.583 & -7.855 & avg30 & -0.388 & 0.17 & 0.077 & 0.743 & 0.097 & -194.292 & & NoTrend \\
\hline $7^{\mathrm{d}}$ & 07105900 & FishCPUE & 0.111 & 0.721 & 37.083 & $-73,636.875$ & 789.375 & 42.28 & cv240 & -0.4 & 0.252 & 0.244 & 0.371 & 65.991 & $-132,748.021$ & & NoTrend \\
\hline $7^{\mathrm{d}}$ & 07105900 & FishLTsim & -0.444 & 0.118 & -0.012 & 24.946 & 0.82 & -11.718 & cv240 & -0.742 & 0.022 & -0.222 & 0.466 & -0.005 & 10.639 & & NoTrend \\
\hline $7^{\mathrm{d}}$ & 07105900 & FishRich & 0.277 & 0.344 & 0.111 & -215.5 & 7.5 & 13.333 & avg30 & -0.545 & 0.103 & 0.333 & 0.21 & 0.093 & -187.421 & & NoTrend \\
\hline 7 & 07105900 & InvLTsim & -0.333 & 0.127 & -0.008 & 17.367 & 0.434 & -23.349 & DOY & -0.557 & 0.048 & -0.333 & 0.127 & -0.008 & 15.673 & & end \\
\hline 7 & 07105900 & InvpEPTrich & 0.221 & 0.298 & 0.002 & -3.067 & 0.051 & 39.5 & $\operatorname{cv} 30$ & 0.326 & 0.255 & 0.099 & 0.661 & 0.001 & & & end \\
\hline 7 & 07105900 & InvRich & 0.169 & 0.44 & 0.5 & -976.75 & 24.75 & 26.263 & $\operatorname{cv} 30$ & 0.436 & 0.119 & 0.209 & 0.324 & 0.475 & -956.787 & & NoTrend \\
\hline 8 & 07106000 & FishCPUE & -0.495 & 0.016 & -9.871 & $19,935.77$ & 164.431 & -78.04 & $\operatorname{avg} 240$ & -0.434 & 0.121 & -0.363 & 0.08 & & $11,995.459$ & & BeforeAfter \\
\hline 8 & 07106000 & FishLTsim & -0.564 & 0.009 & -0.017 & 35.487 & 0.826 & -25.121 & $\operatorname{cv} 30$ & 0.614 & 0.026 & -0.487 & 0.024 & -0.013 & 25.463 & -18.412 & BeforeAfter \\
\hline 8 & 07106000 & FishRich & -0.346 & 0.114 & -0.143 & 296.071 & 9.929 & -18.705 & DOY & -0.71 & 0.004 & -0.155 & 0.476 & -0.083 & 167.732 & & NoTrend \\
\hline 8 & 07106000 & InvLTsim & -0.477 & 0.028 & -0.01 & 20.124 & 0.536 & -21.872 & avg 240 & -0.538 & 0.058 & -0.256 & 0.246 & -0.006 & 11.644 & -1 & Before \\
\hline 8 & 07106000 & InvpEPTrich & -0.033 & 0.913 & 0 & 0.728 & 0.182 & -1.941 & DOY & -0.516 & 0.059 & 0.055 & 0.827 & 0.001 & -1.397 & & NoTrend \\
\hline 8 & 07106000 & InvRich & & & 0.273 & -514.545 & 31.727 & 11.175 & cv240 & & 0.238 & 0.165 & 0.443 & 0.241 & -484.958 & & NoTrend \\
\hline 9 & 07106300 & FishCPUE & -0.253 & 0.228 & -5.359 & $10,854.854$ & 120.937 & -57.605 & avg240 & -0.387 & 0.171 & -0.165 & 0.443 & -3.329 & $6,691.345$ & & end \\
\hline 9 & 07106300 & FishLTsim & & 0.2 & 0.008 & & & 14.683 & avg240 & 0.34 & & 0.154 & 0.502 & & & & end \\
\hline 9 & 07106300 & FishRich & 0.061 & 0.819 & 0 & 9 & 9 & 0 & cv240 & -0.309 & 0.283 & 0.033 & 0.913 & 0.017 & -35.098 & & NoTrend \\
\hline 9 & 07106300 & InvLTsim & -0.194 & 0.392 & -0.003 & 6.706 & 0.548 & -6.731 & avg30 & -0.653 & 0.015 & -0.026 & 0.951 & -0.001 & 1.81 & & NoTrend \\
\hline 9 & 07106300 & InvpEPTrich & 0.045 & 0.869 & 0 & -0.759 & 0.233 & 2.762 & cv240 & -0.569 & 0.034 & 0.099 & 0.661 & 0.001 & -2.188 & & NoTrend \\
\hline 9 & 07106300 & InvRich & -0.134 & 0.545 & -0.333 & 704.333 & 36.667 & -11.818 & $\operatorname{avg} 30$ & -0.392 & 0.165 & -0.143 & 0.511 & -0.276 & 555.383 & & NoTrend \\
\hline 10 & 07106500 & FishCPUE & -0.341 & 0.101 & -3.973 & $8,024.701$ & 67.024 & -77.058 & $D O Y$ & -0.354 & 0.214 & -0.275 & 0.189 & -4.391 & $8,808.104$ & -85.168 & Before \\
\hline 10 & 07106500 & FishLTsim & 0.154 & 0.502 & 0.004 & -6.483 & 0.565 & 7.473 & DOY & 0.487 & 0.092 & 0.179 & 0.428 & 0.004 & -7.935 & & NoTrend \\
\hline 10 & 07106500 & FishRich & -0.157 & 0.497 & 0 & 7 & 7 & 0 & $\operatorname{cv} 30$ & 0.673 & 0.008 & -0.077 & 0.743 & -0.048 & 95.85 & & NoTrend \\
\hline 10 & 07106500 & InvLTsim & -0.487 & 0.024 & -0.006 & 13.172 & 0.586 & -12.859 & $c v 30$ & -0.585 & 0.036 & -0.538 & 0.012 & -0.005 & 9.685 & -9.873 & BeforeAfter \\
\hline 10 & 07106500 & InvpEPTrich & 0.089 & 0.7 & 0.001 & -1.026 & 0.188 & 4.194 & DOY & 0.241 & 0.407 & 0.055 & 0.827 & 0 & -0.703 & & NoTrend \\
\hline 10 & 07106500 & InvRich & 0.102 & 0.658 & 0.111 & -187.278 & 35.278 & 4.094 & avg240 & -0.27 & 0.351 & 0.187 & 0.381 & 0.249 & -498.803 & & NoTrend \\
\hline
\end{tabular}

${ }^{\mathrm{a}}$ See figure 1.

bee table 4 for an explanation of the codes

'See table 3 for an explanation of the codes.

dFish sampled 2007-2016. 
explained 6 trends. The second most frequently identified variable was the 240-day average daily streamflow for 240 days prior to sample collection (avg240), which explained four trends. The third most frequently identified variable was the 240-day daily streamflow coefficient of variation for 240 days prior to sample collection (cv240), which explained three trends. The fourth most frequently identified variable was the day of year a sample was collected (DOY), which explained two trends, and the fifth most frequently identified variable was the 30 -day average daily streamflow for 30 days prior to sample collection (avg30), which explained one trend.

Of the 16 metrics that were significant after streamflow adjustment, 5 (all decreasing) were significant after being adjusted for habitat and water quality variables but still had trends that were unexplained with the tested variables (labeled Unexplained; table 6). Eleven of these significant streamflowadjusted trends were explained by water-quality (one trend) or habitat (ten trends).
Trends in invertebrate biology metrics (InvLTsim, InvpEPTrich, and InvRich) were analyzed before streamflow adjustment, and seven significant trends were found with year (one increasing and six decreasing; table 5). Six of these trends were in the metric InvLTsim (one increasing and five decreasing). Once antecedent streamflow was accounted for, there were seven significant trends (one increasing and six decreasing) and five of these trends were for InvLTsim with the average change being a decrease of 12.7 percent. These seven streamflow-adjusted trends were explored further by analyzing if water quality and habitat influenced these changes. Five of these trends were explained by habitat (three explained by Lbcap and two by maxBH; table 6). Two streamflowadjusted trends were still significant and were not explained by either habitat or water quality, and both were decreasing trends. The greatest number of trends (six) was found for the metric InvLTsim. One InvLTsim trend was explained by streamflow and three were explained by habitat; however,

Table 6. Streamflow-adjusted significant monotonic trends in invertebrate and fish metrics explained by habitat and water-quality variables in the Fountain Creek Basin, Colorado, 2003-2016.

[Italicized and bolded text indicates a significant trend. ID, identification; USGS, U.S. Geological Survey; $y$, biological endpoint being assessed for trend; $\mathrm{x}$, environmental variable most strongly correlated with the associated biological metric; rCorr, Pearson's correlation coefficient between $\mathrm{x}$ and $\mathrm{y}$; $\mathrm{pCorr}, \mathrm{p}$ value associated with rCorr; tauR, test statistic Kendall's tau associated with the data adjusted for $\mathrm{x} ; \mathrm{pR}, \mathrm{p}$ value associated with tauR; slopeR, median change in residual units per year calculated as Sen Slope (Sen, 1968); interceptR, intercept computed from the median of the residuals (the biological metric adjusted for $\mathrm{x})$ and time, also known as the Conover method (Conover, 1999)]

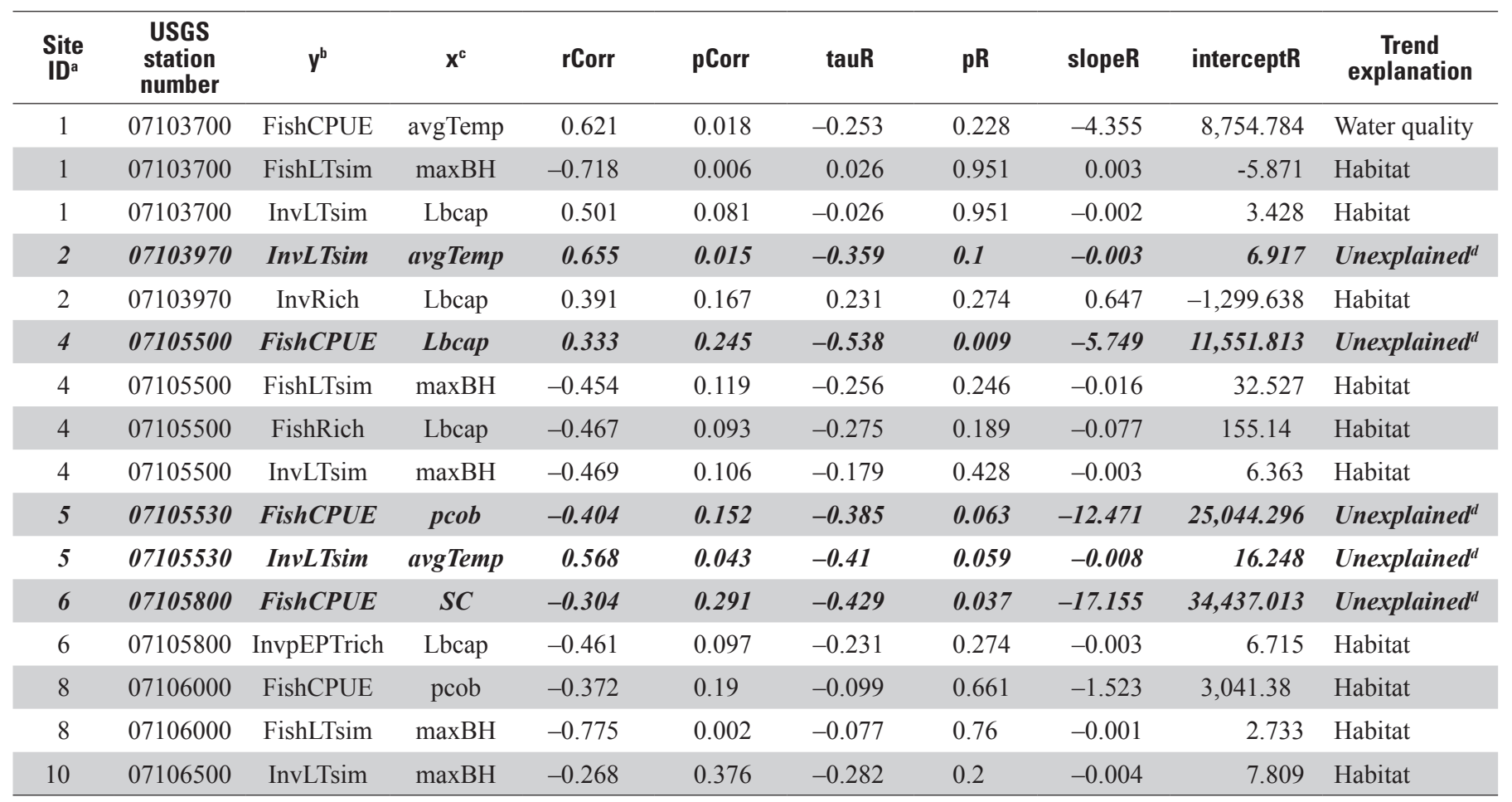

a See figure 1.

${ }^{\mathrm{b} S e e}$ table 4 for an explanation of the codes.

'See table 3 for an explanation of the codes.

dHabitat and water-quality variables have been included, but there is still a significant trend that is unexplained with the tested variables. 
two streamflow-adjusted trends were unexplained by habitat or water quality (fig. 4A). There are three trends in the other two invertebrate metrics, and two (InvpEPTrich and InvRich) were explained by habitat and one (InvRich) by streamflow.

Similar results were obtained from the analysis of the 3 fish biological metrics at the 10 sites. Of the 30 fish trends analyzed, there were 12 significant trends between metrics and year before streamflow adjustment (all decreasing), and these trends have an average decline of 54.8 percent (table 5). Incorporating streamflow into the analysis of fish biological metrics resulted in nine significant trends (all decreasing) at five sites with an average decrease of 44.4 percent. The most frequently identified streamflow explanatory variable was cv30 (explained four); the second most frequently identified variable was avg240 (three); the third most frequently identified variables were avg30 (one) and DOY (one). Of the significant streamflow-adjusted trends, one was explained by water quality (average temperature) and five were explained by habitat metrics (maxBH [three], Lbcap [one], and pcob [one]; table 6). The three streamflow-adjusted trends left unexplained by water quality or habitat all were decreasing.

There were 14 trends found for the 3 fish biological metrics but only 1 (explained by habitat) for FishRich (fig. 4B). The remainder of the trends were split evenly, and this analysis identified seven trends for FishCPUE and six trends for FishLTsim. The greatest number of trends were explained by habitat (five) and streamflow (five). One trend was explained by water quality, and three streamflow-adjusted trends in FishCPUE were not explained by this analysis.

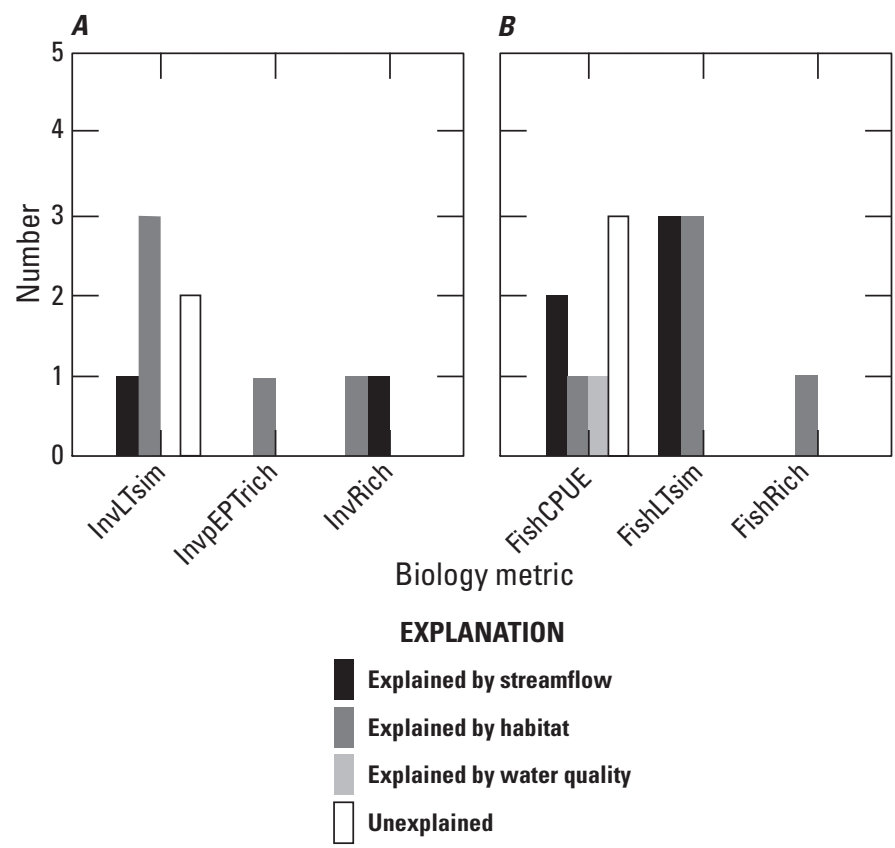

Figure 4. Number of trends for $A$, invertebrate and $B$, fish metrics explained by streamflow, habitat, or water-quality variables and the number unexplained by the data. Metric descriptions are provided in table 4.
Comparing the trends among fish and invertebrate metrics indicated that streamflow masked two trends in both fish and invertebrates (fig. 5). In total, streamflow explained the most fish trends (21.7 percent of all fish trends) and habitat explained the most invertebrate trends (31.3 percent of all invertebrate trends). Water quality explained one trend overall and it was for fish (fig. 5). These results indicate that streamflow is the most frequently identified explanatory variable for trends in fish and invertebrates; however, habitat is the second most frequently identified explanatory variable for these trends. Overall, a similar percentage of fish and invertebrate trends were unexplained (that is, 13 percent and 12.5 percent, respectively) by the tested variables (fig. 5).

This study analyzed 19 trends for 4 fish species (ARD, $\mathrm{CRC}, \mathrm{FHC}$, and WHS). To determine if there were trends in CPUE for these species, one site (site 7) was analyzed for ARD_CPUE, two sites (sites 6 and 8) for FHC_CPUE, seven sites (sites 2-8) for CRC_CPUE, and nine sites (sites 2-10) for WHS_CPUE (table 7). Trends in WHS_CPUE were found at two sites and antecedent streamflow did not mask or explain either of these (table 7). The WHS_CPUE trend at site 8 was a decrease of 71 percent and the trend at site 7 was an increase of 1,458 percent. Both of these trends were

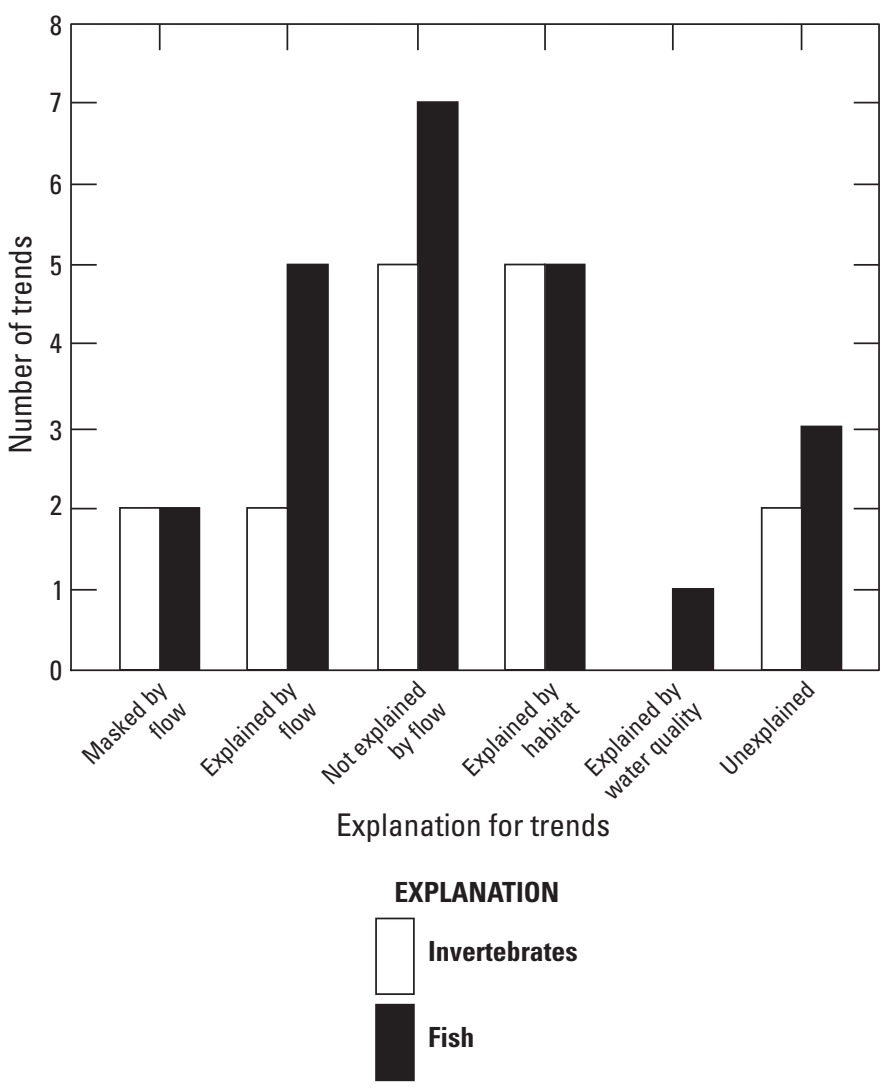

Figure 5. Number of trends in fish and invertebrate metrics related to streamflow (masked by streamflow, explained by streamflow, or not explained by streamflow), explained by habitat, or explained by water-quality variables and the number unexplained given the data. 
Table 7. Monotonic trends in fish metrics explained by antecedent streamflow variables in the Fountain Creek Basin, Colorado, 2003-2016.

[Italicized and bolded text indicate a significant trend. Because predicted values were used for this calculation, some changes are less than -100 percent, which is not possible for biological population data, so values less than or equal to -100 percent are presented as “- $-100 \%$ *." ID, identification; USGS, U.S. Geological Survey; y, biological endpoint being assessed for trend; tauO, test statistic Kendall's tau associated with the unadjusted data; pO, p value associated with tauO; slopeO, median change in metric units per year calculated as Sen Slope (Sen, 1968); interceptO, intercept computed from the median of the biological metric and time, also known as the Conover method (Conover, 1999); firstPred, first years predicted value calculated as slopeOxfirstYear+interceptO; Per.ChangeO, percentage change of the trend period for the unadjusted response variable calculated as 100x((slopeOx(lastYear-firstYear))/firstPred; $\mathrm{x}$, environmental variable most strongly correlated with the associated biological metric; rCorr, Pearson's correlation coefficient between $\mathrm{x}$ and $\mathrm{y}$; $\mathrm{pCorr}, \mathrm{p}$ value associated with rCorr; tauR, test statistic Kendall's tau associated with the data adjusted for $\mathrm{x}$; $\mathrm{pR}$, $\mathrm{p}$ value associated with tauR; slopeR, median change in residual units per year calculated as Sen Slope (Sen, 1968); interceptR, intercept computed from the median of the residuals (the biological metric adjusted for x) and time, also known as the Conover method (Conover, 1999); Per.ChangeR, percentage change over trend period after the response variable has been adjusted for x calculated as 100x((slopeRx(lastYear-firstYear))/firstPred; Results, indicates what types of trends were found in relation to streamflow adjustment (that is, Before [prior to streamflow adjustment], BeforeAfter [prior to and after streamflow adjustment], After [after streamflow adjustment], or NoTrend)]

\begin{tabular}{|c|c|c|c|c|c|c|c|c|c|c|c|c|c|c|c|c|c|}
\hline $\begin{array}{l}\text { Site } \\
\text { ID }^{\mathrm{a}}\end{array}$ & $\begin{array}{l}\text { USGS } \\
\text { station } \\
\text { number }\end{array}$ & $y^{b}$ & tau0 & p0 & slope0 & intercept0 & firstPred & $\begin{array}{c}\text { Per. } \\
\text { Change0 }\end{array}$ & $x^{c}$ & rCorr & pCorr & tauR & $\mathrm{pR}$ & slopeR & interceptR & $\begin{array}{c}\text { Per. } \\
\text { ChangeR }\end{array}$ & Results \\
\hline 2 & 07103970 & $C R C$ & -0.487 & 0.024 & -16.842 & $4,019.906$ & 268.481 & -75.277 & avg240 & -0.463 & 0.111 & -0.154 & 0.502 & -5.789 & $11,563.863$ & -25.874 & Before \\
\hline 2 & 07103970 & WHS & -0.065 & 0.807 & -0.194 & 410.2 & 21.618 & -10.763 & DOY & 0.818 & 0.001 & -0.179 & 0.428 & -0.394 & 789.996 & & NoTrend \\
\hline 3 & 07104905 & $C R C$ & 0.055 & 0.827 & 0.208 & -405.264 & 10.664 & 25.314 & $\operatorname{avg} 30$ & 0.88 & 0 & -0.451 & 0.029 & -1.235 & $2,479.313$ & $-100 *$ & After \\
\hline 3 & 07104905 & WHS & 0.297 & 0.155 & 1.105 & $-2,206.782$ & 7.434 & 193.325 & $\operatorname{avg} 30$ & 0.809 & 0 & 0.121 & 0.584 & 0.792 & $-1,591.903$ & & NoTrend \\
\hline 4 & 07105500 & $C R C$ & -0.534 & 0.011 & -0.708 & $1,426.656$ & 9.439 & -97.451 & $c v 30$ & 0.747 & 0.002 & -0.165 & 0.443 & -0.332 & 665.682 & -45 & Before \\
\hline 4 & 07105500 & WHS & -0.011 & 1 & -0.004 & 19.072 & 10.667 & -0.511 & $\operatorname{cv} 30$ & 0.744 & 0.002 & 0.143 & 0.511 & 0.738 & $-1,481.439$ & & NoTrend \\
\hline 5 & 07105530 & $C R C$ & -0.385 & 0.063 & -0.602 & $1,215.365$ & 9.108 & -85.961 & cv30 & 0.765 & 0.001 & -0.275 & 0.189 & -0.386 & 776.165 & -55.049 & Before \\
\hline 5 & 07105530 & WHS & -0.011 & 1 & -0.084 & 181.713 & 12.598 & -8.713 & $\operatorname{cv} 30$ & 0.869 & 0 & 0.033 & 0.913 & 0.281 & -564.336 & & NoTrend \\
\hline 6 & 07105800 & $F H C$ & -0.451 & 0.029 & -7.507 & $15,120.909$ & 84.29 & $-100 *$ & avg240 & -0.382 & 0.177 & -0.363 & 0.08 & -7.243 & $14,533.461$ & $-100 *$ & BeforeAfter \\
\hline 6 & 07105800 & $C R C$ & -0.341 & 0.101 & -0.394 & 796.296 & 7.569 & -67.632 & $D O Y$ & -0.482 & 0.081 & -0.297 & 0.155 & -0.564 & 1,135 & -96.94 & Before \\
\hline 6 & 07105800 & WHS & -0.121 & 0.584 & -0.364 & 745.13 & 15.499 & -30.553 & $\operatorname{cv} 30$ & 0.641 & 0.014 & 0.055 & 0.827 & 0.211 & -427.173 & & NoTrend \\
\hline $7^{\mathrm{d}}$ & 07105900 & $\mathrm{CRC}$ & 0.067 & 0.858 & 14.583 & $-29,009.375$ & 259.375 & 50.602 & cv240 & -0.501 & 0.14 & 0.2 & 0.474 & 22.621 & $-45,564.521$ & & NoTrend \\
\hline $7^{d}$ & 07105900 & WHS & 0.539 & 0.039 & 19.643 & $-39,411.607$ & 11.607 & $1,523.077$ & avg240 & 0.493 & 0.147 & 0.467 & 0.074 & 18.802 & $-37,820.363$ & $1,457.88$ & BeforeAfter \\
\hline $7^{\mathrm{d}}$ & 07105900 & ARD & -0.378 & 0.152 & -45.139 & $90,950.804$ & 357.054 & $-100^{*}$ & cv240 & -0.812 & 0.004 & -0.067 & 0.858 & -3.616 & $7,260.07$ & & NoTrend \\
\hline 8 & 07106000 & $F H C$ & -0.407 & 0.049 & -5.487 & $11,095.262$ & 103.875 & -68.676 & avg240 & -0.484 & 0.079 & -0.297 & 0.155 & -2.908 & $5,828.42$ & -36.388 & Before \\
\hline 8 & 07106000 & $\mathrm{CRC}$ & -0.089 & 0.7 & -0.053 & 107.592 & 1.287 & -53.609 & cv240 & -0.37 & 0.193 & -0.121 & 0.584 & -0.059 & 119.123 & & NoTrend \\
\hline 8 & 07106000 & WHS & -0.407 & 0.049 & -0.672 & $1,355.686$ & 10.478 & -83.323 & cv30 & 0.462 & 0.096 & -0.429 & 0.037 & -0.576 & $1,155.674$ & -71.438 & BeforeAfter \\
\hline 9 & 07106300 & WHS & -0.319 & 0.125 & -0.532 & $1,072.562$ & 6.54 & $-100^{*}$ & $\operatorname{cv} 30$ & 0.529 & 0.052 & -0.231 & 0.274 & -0.181 & 360.862 & & NoTrend \\
\hline 10 & 07106500 & WHS & -0.011 & 1 & -0.001 & 3.167 & 1.276 & -0.961 & $\operatorname{cv} 30$ & 0.723 & 0.003 & 0.077 & 0.743 & 0.045 & -91.667 & $-100 *$ & NoTrend \\
\hline
\end{tabular}

\section{${ }^{\text {a See figure } 1 .}$}

bee table 4 for an explanation of the codes.

'See table 3 for an explanation of the codes.

'Fish sampled 2007-2016. 
explained by habitat and water quality; Lbcap explained the increasing trend at site 7 and average temperature explained the decrease at site 8 (table 8). The analysis for trends of CRC_CPUE found four sites with trends explained by antecedent streamflow (cv30 [two], avg240 [one], and DOY [one]) and one trend that was masked by streamflow (site 3; table 7). The one streamflow-adjusted trend at site 3 was explained by the habitat variable maxBH (table 8 ). These results for the most ubiquitous native (WHS_CPUE) and nonnative (CRC_CPUE) fish species indicate both are more stable (that is, fewer increasing or decreasing trends) than the basin-wide fish metric trends.

The analysis of the two fish species of conservation concern (ARD and FHC) in the FCB found no trends for ARD_CPUE and two trends for FHC_CPUE, with one trend explained by streamflow (site $8 ;-36$ percent change; avg240) and one trend not explained by streamflow (site $6 ;-100^{*}$ percent change; table 7). The FHC_CPUE trend at site 6 was explained by the habitat variable Lbcap (table 8 ). These results indicate that, although the ARD is not widespread in the FCB, its population is not changing, but the FHC population is declining and the explanatory variables (avg240 and Lbcap) for these decreasing FHC_CPUE trends are related to streamflow regime shifts and habitat changes. A recent study reports that greater occurrences of peak flow days (greater than 98 percent of daily average discharge) can reduce growth and survival of age- 0 FHC (Haworth and Bestgen, 2017). The analysis in this report examined this relationship at sites 6 and 8 from 2003 to 2016 and found that, if there are greater than 25 peak flow days from May to August, there is a decline in age-0 FHC (that is, FHC less than $6 \mathrm{~cm}$ total length) that year (fig. 6).

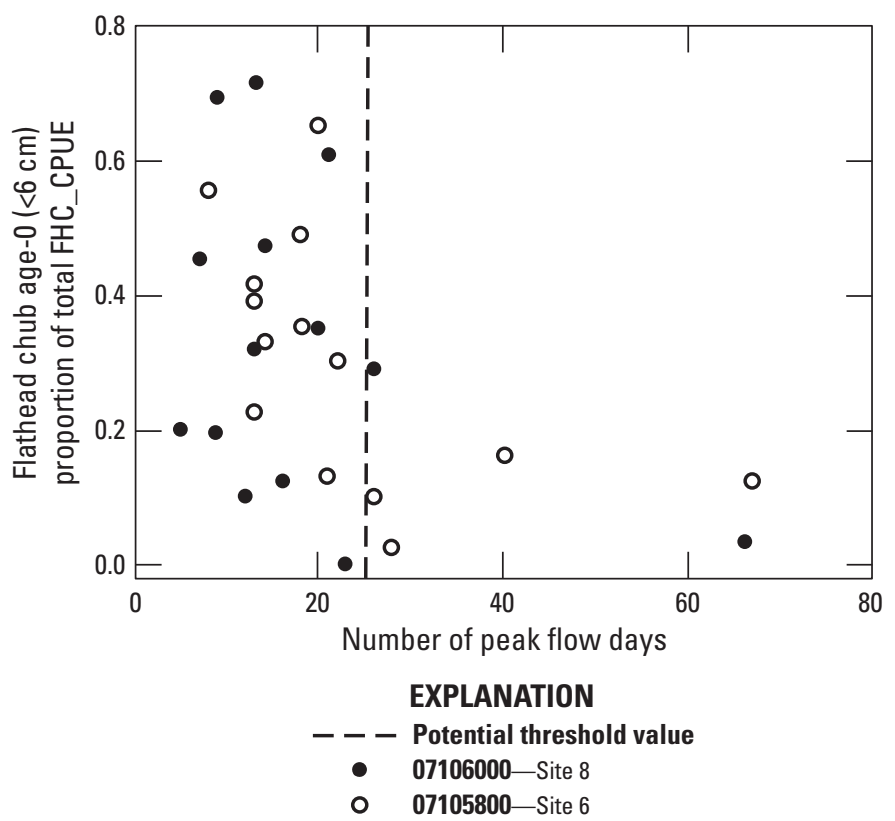

Figure 6. Scatterplot of flathead chub age-0 fish versus the number of peak flow days in a year. The two sites (sites 6 and 8) shown in this figure represent the most robust flathead chub sampling sites in this dataset. The dashed grey line (peak flow days $=25$ ) is a potential threshold value above which there is little to no production of age-0 flathead chub. (cm, centimeter; FHC_CPUE, the number of flathead chub captured divided by the product of surface acres sampled and the number of nets)

Table 8. Monotonic trends in fish metrics explained by habitat and water-quality variables in the Fountain Creek Basin, Colorado, 2003-2016.

[ID, identification; USGS, U.S. Geological Survey; y, biological endpoint being assessed for trend; $\mathrm{x}$, environmental variable most strongly correlated with the associated biological metric; rCorr, Pearson's correlation coefficient between $\mathrm{x}$ and $\mathrm{y}$; pCorr, $\mathrm{p}$ value associated with rCorr; tauR, test statistic Kendall's tau associated with the data adjusted for $\mathrm{x} ; \mathrm{pR}, \mathrm{p}$ value associated with tauR; slopeR, median change in residual units per year calculated as Sen Slope (Sen, 1968); interceptR, intercept computed from the median of the residuals (the biological metric adjusted for $\mathrm{x}$ ) and time, also known as the Conover method (Conover, 1999)]

\begin{tabular}{cccccccccrrr}
\hline $\begin{array}{c}\text { Site } \\
\text { ID }^{\mathbf{a}}\end{array}$ & $\begin{array}{c}\text { USGS } \\
\text { station } \\
\text { number }\end{array}$ & $\mathbf{y}^{\mathbf{b}}$ & $\mathbf{x}^{\mathbf{c}}$ & rCorr & pCorr & tauR & pR & slopeR & $\begin{array}{c}\text { interceptR } \\
\text { Trend } \\
\text { explanation }\end{array}$ \\
\hline 3 & 07104905 & CRC & maxBH & -0.501 & 0.068 & -0.011 & 1 & -0.029 & 56.201 & Habitat \\
6 & 07105800 & FHC & Lbcap & -0.375 & 0.186 & -0.231 & 0.274 & -4.821 & $9,660.869$ & Habitat \\
\hline $7^{\text {d }}$ & 07105900 & WHS & Lbcap & 0.524 & 0.12 & 0.111 & 0.721 & 4.972 & $-1,0013.5$ & Habitat \\
8 & 07106000 & WHS & avgTemp & -0.611 & 0.02 & -0.253 & 0.228 & -0.539 & $1,083.733$ & Water quality \\
\hline
\end{tabular}

${ }^{\text {a See figure } 1 .}$

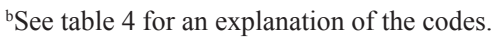

'See table 3 for an explanation of the codes.

'Fish sampled 2007-2016. 


\section{Major Findings}

Overall, before adjustments for streamflow, 19 trends were found in the fish (12) and invertebrate (7) metrics and all were decreasing except for invertebrate species richness at the most upstream site (site 2 on Monument Creek). Seven of these trends were explained by streamflow, and four additional trends were found after adjusting for antecedent streamflow. Two sites (sites 7 and 9) had no trends in the fish or invertebrate metrics. After adjusting for antecedent streamflow, 10 trends were explained by habitat, 1 was explained by water quality, and 5 were unexplained. Overall, all the fish metric trends were decreasing from 2003 to 2016 with an average decline of 40 percent, and invertebrate metrics decreased on average by 9.5 percent. This trends analysis identified that both fish and invertebrate metric values declined across the majority of sampled sites in the FCB, but the mean decrease for fish populations was greater than that of the invertebrate metrics. The species-specific results indicated that the populations of the most widespread and abundant fish species (CRC, WHS) were more stable when compared to the results for FHC and ARD. The two species of conservation concern (FHC and ARD) are abundant in disjunct regions of the FCB. Although ARD_CPUE was stable at the one site where it was consistently found (site 7), FHC_CPUE was declining at both sites examined for this study by an average of about 70 percent. Results from this analysis also indicate that the number of age-0 FHC was negatively related to the number of peak flow days from May through August, with little to no survival of this age class when there were more than 25 days with peak flows greater than the 98th percentile of daily average streamflow. This information could be important for water-resource management decisions related to the conservation of biological communities in the FCB. However, more details on how the time of occurrence and frequency of peak flows, beyond simply the occurrence number, influence the number of age- $0 \mathrm{FHC}$ could be important if this information is to be incorporated into water management plans. Solutions that minimize the effect of the anthropogenic flow alteration on the aquatic fauna could also be important for water management plans in FCB. For example, Ziegler and others (1999) describe an artificial recharge system that would attenuate peak streamflow magnitudes and frequency to help meet future water-supply demands that may also benefit FHC.

These results indicate that both fish and invertebrate communities in the FCB changed over the trend period. This analysis highlights how important consistent, longterm monitoring data are for detecting these types of trends. However, this analysis could have been more complete and provided further information on the influence of water quality and habitat, specifically nutrients, on trends of FCB biological communities. Although the habitat metrics included in this analysis represent many detailed aspects of the channel function and form, they do not capture important transient cover and scour structures (that is, small woody debris and root wads) or the presence of anthropogenic long-term flow break structures (that is, bridge pylons or rip rap). These additional habitat data could help tease out site-specific drivers of biological trends. DNO23 was found to be important to the structure of biological communities in FCB (Zuellig and others, 2008). However, sampling for the water quality-variable DNO23 was replaced by total nitrogen at six sites starting in 2013 and there is no robust technique to predict $\mathrm{DNO} 23$ from this measure. Therefore, how nutrient levels in the FCB are related to trends in biological communities were not able to be analyzed. Based on these results, data consistency was found to help maximize the utility of FCB monitoring data.

\section{Future Directions}

Results from this study indicate that antecedent streamflow and habitat are associated with changes in fish and invertebrate community attributes in the FCB over the study period. Additionally, there is evidence that streamflow characteristics are associated with variability in the growth and survival of young individuals of at least one Statelisted fish species. These results, combined with previous studies (Zuellig and others, 2008, 2010, 2014) have greatly improved our understanding of several drivers of ecological change in the basin. Thus far, studies have been observational in nature and mostly focused on linking habitat and streamflow characteristics, along with limited chemistry, to patterns in fish and invertebrate communities. Building on previous studies, the next steps could be to first reevaluate the program's goals and objectives, and design studies that support moving efforts forward.

Although previous studies have done well at characterizing the environment and biology in the FCB, several questions remain. For example, streamflow is a major driver of biological communities in the FCB, yet there are both natural and anthropogenic components that govern streamflow. However, the proportional influence of the two factors (natural and anthropogenic) that govern streamflow in FCB is unknown. Understanding both the natural and human-induced components of streamflow could lead to well-targeted management efforts that mitigate and maintain a high-quality ecological condition in the FCB. Additionally, connecting fish and invertebrate life histories with specific habitat needs and streamflow conditions could provide direct strategies for integrating ecological and water management of the FCB. Finally, integrating observational studies with laboratory experiments and modeling could help develop causal linkages between individual stressors and changes in aquatic communities in the FCB. 


\section{Summary}

The Fountain Creek Basin encompasses approximately 926 square miles in south-central Colorado draining the eastern slope of the Rocky Mountains. The analysis described in this report is part of a long-term project monitoring the biological communities, habitat, and water quality of the Fountain Creek Basin (FCB). The data presented and analyzed included annual samples of aquatic invertebrate communities, fish communities, water quality, and quantitative riverine habitat. To analyze and interpret how the aquatic biological communities of the FCB are changing, the U.S. Geological Survey, in cooperation with the City of Colorado Springs, Water Resources Engineering Division, Public Works Department and Colorado Springs Utilities, performed a trend analysis for the period 2003-2016 that included important covariates, such as antecedent streamflow, water quality, and habitat. Trends in the biological metrics were detected at 8 of the 10 sites sampled throughout the Fountain Creek Basin. Six biological metrics (three invertebrate and three fish) and four individual fish species were used to examine trends in these data and how streamflow, habitat, and water quality may explain these trends. Most of these trends were decreasing even after being adjusted for antecedent streamflow measures. Of the 60 trends (79 total trends analyzed) tested before being adjusted for streamflow for the 6 biological metrics, 19 trends were found in the fish (12) and invertebrate (7) metrics, and all were decreasing except for invertebrate species richness at the most upstream site in Monument Creek. Seven of these trends were explained by streamflow, and four trends were found to be masked by streamflow. Two sites (sites 7 and 9) had no trends in the fish or invertebrate metrics. All the fish metric trends were decreasing with an average decline of 40 percent, and invertebrate metrics decreased on average by 9.5 percent. This trends analysis identified that both fish and invertebrate metric values declined across the majority of sampled sites in the Fountain Creek Basin, but the mean decrease for fish populations was greater than that of the invertebrate metrics. The speciesspecific results indicated that the populations of the most widespread and abundant fish species, creek chub (Semotilus atromaculatus) and white sucker (Catostomus commersonii), were more stable when compared to the results for the two fish species of conservation concern, flathead chub (Platygobio gracilis) and Arkansas darter (Etheostoma cragini). Results from this analysis indicate that the number of age- 0 flathead chub was negatively related to the number of peak flow days from May through August, with little to no survival of this age class when there were more than 25 days with peak flows greater than the 98th percentile of daily average streamflow. This information could be important for waterresource management decisions related to the conservation of biological communities in the Fountain Creek Basin. Solutions that minimize the impact of the anthropogenic flow alteration on the aquatic fauna could be important for water management plans in the Fountain Creek Basin. For example, this analysis highlights the importance of long-term monitoring for detecting trends in biological communities, and that data consistency helps in maximizing the utility of monitoring data.

Results from this study indicate that antecedent streamflow and habitat are associated with changes over the study period in fish and invertebrate community attributes in the FCB. Building on previous studies, the next steps could be to first reevaluate the program's goals and objectives and design studies that support moving efforts forward. For example, streamflow is a major driver of biological communities in the FCB but there are both natural and anthropogenic components that govern streamflow. However, the proportional influence of the two factors (natural and anthropogenic) that govern streamflow in FCB is unknown. Finally, integrating observational studies with laboratory experiments and modeling could help develop causal linkages between individual stressors and changes in aquatic communities in the FCB.

\section{References Cited}

Barbour, M.T., Gerritsen, J., Snyder, B.D., and Stribling, J.B., 1997, Revision to Rapid Bioassessment Protocols for use in streams and rivers - Periphyton, benthic macroinvertebrates and fish (Draft): Washington, D.C., U.S. Environmental Protection Agency Office of Water, EPA 841-D-97-002, 322 p.

Bestgen, K.R., Wilcox, C.T., Hill, A.A., and Fausch, K.D., 2017, A dynamic flow regime supports an intact Great Plains stream fish assemblage: Transactions of the American Fisheries Society, v. 146, p. 903-916.

Biggs, B.J.F., Nikora, V.I., and Snedler, T.H., 2005, Linking scales of flow variability to lotic ecosystem structure and function: River Research and Applications, v. 21, no. 2-3, p. 283-298.

Bray, J.R., and Curtis, J.T., 1957, An ordination of the upland forests communities of southern Wisconsin: Ecological Monographs, v. 27, p. 325-349.

Carlisle, D.M., Wolock, D.M., and Meador, M R., 2011, Alteration of streamflow magnitudes and potential ecological consequences - A multiregional assessment: Frontiers in Ecology and the Environment, v. 9, no. 5, p. 264-270.

Clarke, K.R., and Warwick, R.M., 2001, Change in marine communities - An approach to statistical analysis and interpretation (1st ed.): Plymouth, United Kingdom, Plymouth Marine Laboratory, 172 p.

Colorado Parks and Wildlife, 2017, Threatened and Endangered List: Colorado Parks and Wildlife, accessed June 27, 2017, at http://cpw.state.co.us/learn/Pages/SOCThreatenedEndangeredList.aspx.

Conover, W.J., 1999, Practical nonparametric statistics, Third Edition: New York, Wiley, 592 p. 
Cuffney, T.F., Gurtz, M.E., and Meador, M.R., 1993, Methods for collecting benthic invertebrate samples as part of the National Water-Quality Assessment Program: U.S. Geological Survey Open-File Report 93-406, 66 p., accessed June 27, 2017, at https://pubs.er.usgs.gov/publication/ ofr93406.

Dodds, W.K., Gido, K, Whiles, M.R., Fritz, K.M., and Matthews, W.J., 2004, Life on the edge-The ecology of Great Plains prairie streams: Bioscience, v. 54, no. 3, p. 205-216.

Durham, B.W., and Wilde, G.R., 2006, Influence of steam discharge on reproductive success of a prairie stream fish assemblage: Transactions of the American Fisheries Society, v. 135 , p. $1644-1653$.

Edelmann, P., Ferguson, S.A., Stogner, R.W., Sr., August, M., Payne, W.F., and Bruce, J.F., 2002, Evaluation of water quality, suspended sediment, and stream morphology with an emphasis on effects of stormflow on Fountain and Monument Creek Basins, Colorado Springs and vicinity, Colorado, 1981 through 2001: U.S. Geological Survey Water-Resources Investigations Report 02-4104, 59 p.

Falke, J.A., Fausch, K.D., Magelky, R., Aldred, A., Durnford, D.S., Riley, L.K., and Oad, R., 2011, The role of groundwater pumping and drought in shaping ecological futures for stream fishes in a dryland river basin of the western Great Plains, USA: Ecohydrology, v. 4, no. 5, p. 682-697.

Fausch, K.D., and Bestgen, K.R., 1997, Ecology of fishes indigenous to the central and southwestern Great Plains, in Knopf, F.L., and Samson, F.B., eds., Ecology and conservation of Great Plains vertebrates-Ecological studies (analysis and synthesis): New York, Springer, Inc., v. 125, p. 131-166.

Fritz, K.M., and Dodds, W.K., 2005, HarshnessCharacterisation of intermittent stream habitat over space and time: Marine \& Freshwater Research, v. 56, no.1, p. 13-23.

Gurtz, M.E., Van Sickle, J., Carlisle, D.M., and Paulsen, S.G., 2013, Design tradeoffs for trend assessment in aquatic biological monitoring programs: U.S. Geological Survey OpenFile Report 2013-1222, 15 p., plus 1 app., accessed June 27, 2017, at https://pubs.er.usgs.gov/publication/ofr20131222.

Hansen, W.R., Crosby, E.J., and Shroba, R.R., 1982, Environmental geology of the Front Range urban corridor and vicinity, Colorado, with a specific section on physical properties and performance characteristics of surficial deposits and rock units in the greater Denver area: U.S. Geological Survey Professional Paper 1230, 99 p.

Harrell, F.E., Jr., with contributions from Charles Dupont and many others, 2017, Hmisc - Harrell Miscellaneous, R package, version 4.0-3, accessed June, 27, 2017, at https:// cran.r-project.org/web/ packages/Hmisc/index.html.

Haworth, M.R., and Bestgen, K.R., 2016, Daily increment validation and effects of streamflow variability and water temperature on growth of age- 0 flathead chub: North American Journal of Fisheries Management, v. 36, no. 4, p. 744-753. [Also available at https://doi.org/10.1080/0275 5947.2016.1165772.]

Haworth, M.R., and Bestgen, K.R., 2017, Flow and water temperature affect reproduction and recruitment of a Great Plains cyprinid: Canadian Journal of Fisheries and Aquatic Sciences, v. 74, no. 6, p. 853-863.

Kiernan, J.D., Moyle, P.B., and Crain, P.K., 2012, Restoring native fish assemblages to a regulated California stream using the natural flow regime concept: Ecological Applications, v. 22, no. 5, p. 1472-1482.

Lorenz, D.L., 2016, smwrStats-An R package for the analysis of hydrologic data, version 0.7 .5 , accessed June 27, 2017, at https://github.com/USGS-R/smwrStats/tree/v0.7.5.

Mau, D.P., Stogner, R.W., Sr., and Edelman, Patrick, 2007, Characterization of stormflows and wastewater treatmentplant effluent discharges on water quality, suspended sediment, and stream morphology for Fountain and Monument Creek watersheds, Colorado, 1981-2006: U.S. Geological Survey Scientific Investigations Report 2007-5104, 76 p.

Meador, M.R., Hupp, C.R., Cuffney, T.F., and Gurtz, M.E., 1993, Methods for characterizing stream habitat as part of the National Water-Quality Assessment Program: U.S. Geological Survey Open-File Report 93-408, 48 p., accessed June 27, 2017, at https://pubs.er.usgs.gov/publication/ ofr93408.

Moulton, S.R., II, Carter, J.L., Grotheer, S.A., Cuffney, T.F., and Short, T.M., 2000, Methods of analysis by the U.S. Geological Survey National Water-Quality LaboratoryProcessing, taxonomy, and quality control of benthic macroinvertebrate samples: U.S. Geological Survey Open-File Report 00-212, 49 p., accessed June 27, 2017, at https:// pubs.usgs.gov/of/2000/0212/report.pdf.

Oelsner, G.P., Sprague, L.A., Murphy, J.C., Zuellig, R.E., Johnson, H.M., Ryberg, K.R., Falcone, J.A., Stets, E.G., Vecchia, A.V., Riskin, M.L., De Cicco, L.A., Mills, T.J., and Farmer, W.H., 2017, Water-quality trends in the Nation's rivers and streams, 1972-2012-Data preparation, statistical methods, and trend results: U.S. Geological Survey Scientific Investigations Report 2017-5006, 136 p., accessed June 27, 2017, at https://doi.org/10.3133/sir20175006.

Omernik, J.M., 1987, Ecoregions of the conterminous United States: Annals of the Association of American Geographers, v. 77 , p. 118-125. 
Perkin, J.S., Gido, K.B., Costigan, K.H., Daniels, M.D., and Johnson, E.R., 2015, Fragmentation and drying ratchet down Great Plains stream fish diversity: Aquatic Conservation: Marine and Freshwater Ecosystems, v. 25, no. 5, p. 639-655.

Poff, N. L., and Allan, D.J., 1995, Functional organization of stream fish assemblages in relation to hydrological variability: Ecology, v. 76, p. 606-627.

Poff, N.L., Allan, J.D., Bain, M.B., Karr, J.R., Prestegaard, K.L., Richter, B.D., Sparks, R.E., and Stromberg, J.C., 1997, The natural flow regime-A paradigm for river conservation and restoration: Bioscience, v. 47, no. 11, p. 769-784.

Poff, N.L., and Matthews, J.H., 2013, Environmental flows in the Anthropocence-Past progress and future prospects: Current Opinion in Environmental Sustainability, v. 5, no. 6, p. 667-675.

Pusey, B.J., Kennard, M.J., Arthur, J.M., and Arthington, A.H., 1998, Quantitative sampling of stream fish assemblagesSingle- vs multiple-pass electrofishing: Australian Journal of Ecology, v. 23, p. 365-374.

R Development Core Team, 2016, R-A language and environment for statistical computing: Vienna, Austria, The R Foundation for Statistical Computing, version 3.3.1 accessed June 6, 2016, at http://www.R-project.org.

Rahel, F.J., and Thel, LA., 2004, Flathead chub (Platygobio gracilis)_A technical conservation assessment: U.S. Department of Agriculture, Forest Service, Rocky Mountain Region, 54 p., accessed May 17, 2017, at http://www.fs.usda. gov/Internet/FSE_DOCUMENTS/stelprdb5182082.pdf.

Rantz, S.E., and others, 1982, Measurement and computation of streamflow-Volume 2, Computation of discharge: U.S. Geological Survey Water-Supply Paper 2175, 347 p.

Roberts, J.J., Zuellig, R.E, and Bruce, J.B., 2017, Datasets of ecological communities (invertebrates and fish), streamflow, habitat, and water quality to examine the presence of trends in ecological communities from the Fountain Creek Basin, Colorado USA, 2003-2016: U.S. Geological Survey data release, https://doi.org/10.5066/f747493V.

Rolls, R.J., Leigh, C., and Sheldon, F., 2012, Mechanistic effects of low-flow hydrology on riverine ecosystemsEcological principles and consequences of alteration: Freshwater Science, v. 31, no. 4, p. 1163-1186.

Schlosser, I.J., 1985, Flow regime, juvenile abundance, and the assemblage structure of stream fishes: Ecology, v. 66, p. 1484-1490.

Sen, P.K., 1968, Estimates of the regression coefficient based on Kendall's tau: Journal of the American Statistical Association, v. 63 , no. 324 , p. $1379-1389$.
Stogner, R.W., Sr., 2000, Trends in precipitation and streamflow and changes in stream morphology in the Fountain Creek watershed, Colorado, 1939-99: U.S. Geological Survey Water-Resources Investigations Report 00-4130, 43 p.

U.S. Geological Survey [USGS], variously dated, National field manual for the collection of water-quality data: U.S. Geological Survey Techniques of Water-Resources Investigations, Book 9, chaps. A1-A10, accessed June 27, 2017, at http://pubs.water.usgs.gov/twri9A.

Wolman, M.G., 1954, A method of sampling coarse riverbed material: Transactions of the American Geophysical Union, v. 35, p. 951-956.

Ziegler, A.C., Christensen, V.G., and Ross, H.C., 1999, Baseline water quality and preliminary effects of artificial recharge on ground water, south-central Kansas, 1995-98: U.S. Geological Survey Water-Resources Investigations Report 99-4250, 74 p.

Zuellig, R.E., Bruce, J.F., Evans, E.E., and Stogner, R.W., 2008, Urban-related environmental variables and their relation with patterns in biological community structure in the Fountain Creek Basin, Colorado, 2003-2005: U.S. Geological Survey Scientific Investigations Report 2007-5225, 24 p.

Zuellig, R.E., Bruce, J.F., Stogner, R.W., 2010, Temporal change in biological community structure in the Fountain Creek Basin, Colorado, 2001-2008: U.S. Geological Survey Scientific Investigations Report 2010-5103, 19 p.

Zuellig, R.E., Bruce, J.F., Stogner, R.W., and Brown, K.D., 2014, Comparability among four invertebrate sampling methods, Fountain Creek Basin, Colorado, 2010-2012: U.S. Geological Survey Scientific Investigations Report 2014-5049, 13 p., accessed June 27, 2017, at https://doi. org/10.3133/sir20145049.

Publishing support provided by the Science Publishing Network, Denver Publishing Service Center

For more information concerning the research in this report, contact the Director, USGS Colorado Water Science Center

Box 25046, Mail Stop 415

Denver, C0 80225

(303) 236-4882

Or visit the Colorado Water Science Center website at https://co.water.usgs.gov/ 


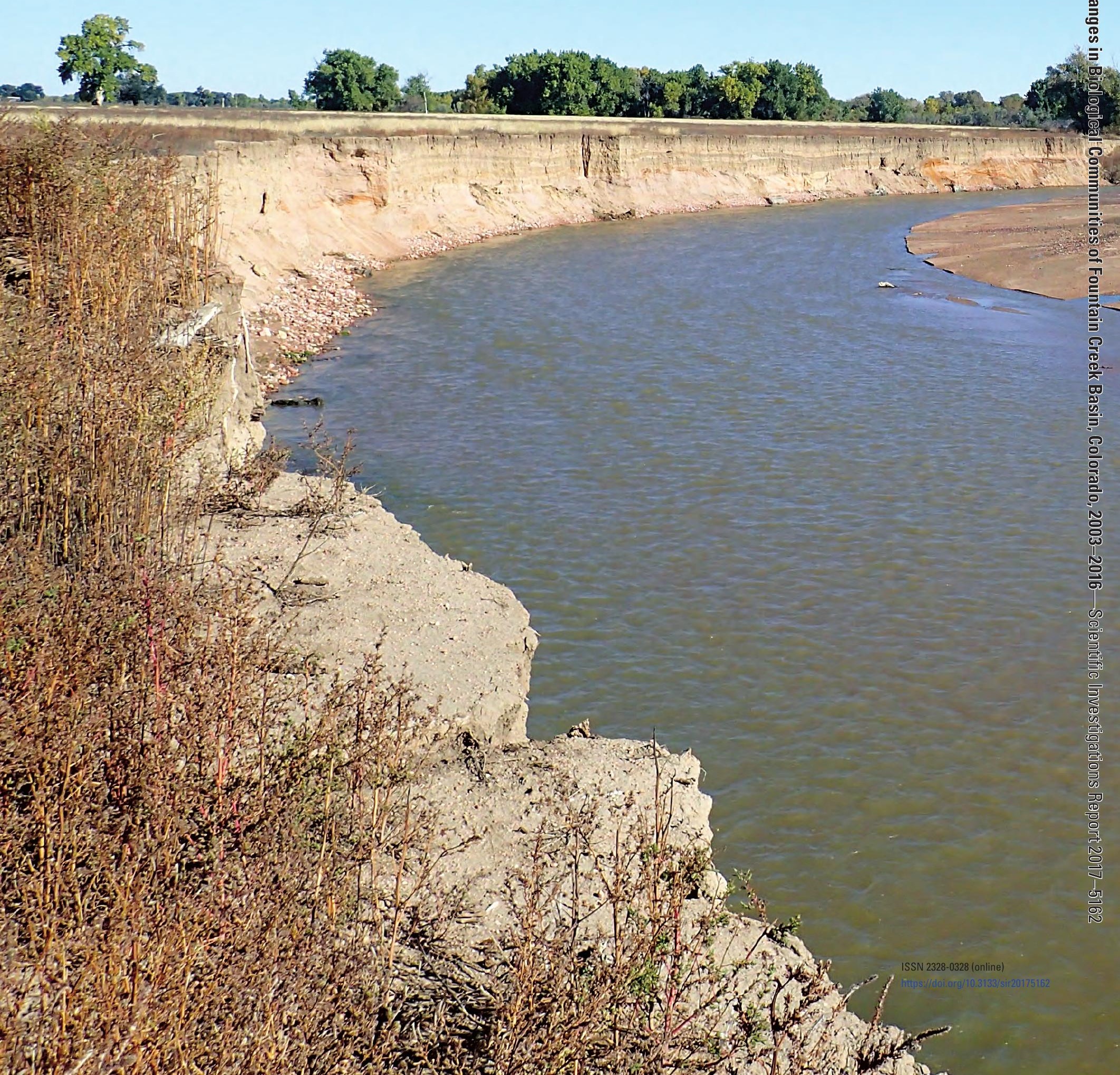